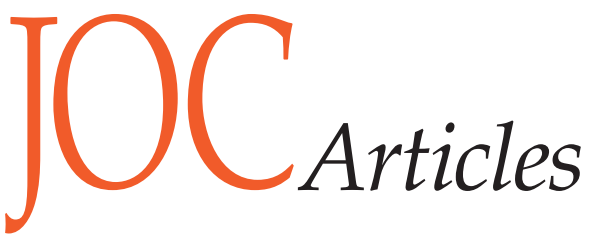

\title{
Single-Site Mutation and Secondary Structure Stability: An Isodesmic Reaction Approach. The Case of Unnatural Amino Acid Mutagenesis Ala $\rightarrow$ Lac
}

\author{
Andrzej Stanisław Cieplak* and Nur Başak Sürmeli \\ Department of Chemistry, Bilkent University, 06800 Bilkent, Ankara, Turkey \\ cieplak@fen.bilkent.edu.tr \\ Received December 18, 2003
}

\begin{abstract}
A method is described to evaluate backbone interactions in proteins via computational unnatural amino acid mutagenesis. Several $\mathrm{N}$-acetyl polyalanyl amides $\left(\mathrm{AcA}_{n} \mathrm{NH}_{2}\right)$ were optimized in the representative helical $\left(3_{10^{-}}, 4_{13^{-}}\right.$, and a "hybrid" $\kappa$-helix, $\left.\mathrm{n}=7,9,10,14\right)$ and hairpin (two- and three-stranded antiparallel $\beta$-sheets with type I turns $\beta \alpha \alpha \epsilon, \mathrm{n}=6,9,10)$ conformations, and extended conformers of $\mathrm{N}$-acetyl polyalanyl methylamides $(\mathrm{n}=2,3)$ were used to derive multistranded $\beta$-sheet fragments. Subsequently, each residue of every model structure was substituted, one at a time, with L-lactic acid. The resulting mutant structures were again optimized, and group-transfer energies $\Delta \mathrm{E}_{\mathrm{GT}}$ were obtained as heats of the isodesmic reactions: $A C A_{n} N H R+$ $\mathrm{AcOMe} \rightarrow \mathrm{AcA}_{x} \mathrm{LacA}_{y} \mathrm{NHR}+\mathrm{AcNHMe}\left(\mathrm{R}=\mathrm{H}, \mathrm{CH}_{3}\right)$. These group-transfer energies correlate with the degree of charge polarization of the substituted peptide linkages as measured by the difference $\Delta \mathrm{e}$ in $\mathrm{H}$ and $\mathrm{O}$ Mulliken populations in $\mathrm{HN}-\mathrm{C}=\mathrm{O}$ and with the $\mathrm{H}$-bond distances in the "wildtype" structures. A good correlation obtains for the HF/3-21G and B3L YP/6-31G* group-transfer energies. The destabilization effects are interpreted in terms of loss of interstrand and intrastrand $\mathrm{H}$-bonds, decrease in Lewis basicity of the $\mathrm{C}=\mathrm{O}$ group, and $\mathrm{O} \cdots \mathrm{O}$ repulsion. On the basis of several comparisons of $\mathrm{Ala} \rightarrow \mathrm{Lac} \Delta \mathrm{E}_{\mathrm{GT}}$ 's with heats of the $\mathrm{NH} \rightarrow \mathrm{CH}_{2}$ substitutions, the latter contribution is estimated (B3LYP/6-31G*) to range between 1.5 and $2.4 \mathrm{kcal} \mathrm{mol}^{-1}$, a figure close to the recent experimental $\Delta \Delta \mathrm{G}^{\circ}$ value of $2.6 \mathrm{kcal} \mathrm{mol}^{-1}$ (McComas, C. C.; Crowley, B. M.; Boger, D. L. J . Am. Chem. Soc. 2003, 125, 9314). The partitioning yields the following maximum values of the electronic association energy of $\mathrm{H}$-bonds in the examined sample of model structures (B3LYP/6-31G* estimates): $3_{10}$-helix $D_{e}=-1.7 \mathrm{kcal} \mathrm{mol}^{-1}, \alpha$-helix $D_{e}=-3.8 \mathrm{kcal} \mathrm{mol}^{-1}, \beta$-sheet $\mathrm{D}_{\mathrm{e}}=-6.1 \mathrm{kcal}$ $\mathrm{mol}^{-1}$. The premise of experimental evaluations of the backbone-backbone $\mathrm{H}$-bonding that $\mathrm{Ala} \rightarrow$ Lac substitution in proteins is isosteric (e.g., Koh, J . T.; Cornish, V. W.; Schultz, P. G. Biochemistry $1997,36,11314$ ) is often but not always corroborated. Examination of the integrity of H-bonding pattern and $\varphi_{i}, \psi_{i}$ distribution identified several mutants with significant distortions of the "wildtype" structure resulting inter alia from the transitions between $\mathrm{i}, \mathrm{i}+3$ and $\mathrm{i}, \mathrm{i}+4 \mathrm{H}$-bonding in helices, observed previously in the crystallographic studies of depsipeptides (Ohyama, T.; Oku, H.; Hiroki, A.; Maekawa, Y.; Y oshida, M.; Katakai, R. Biopolymers 2000, 54, 375; Karle, I. L.; Das, C.; Balaram, P. Biopolymers 2001, 59, 276). Thus, the isodesmic reaction approach provides a simple way to gauge how conformation of the polypeptide chain and dimensions of the $\mathrm{H}$-bonding network affect the strength of backbone-backbone $\mathrm{C}=\mathrm{O} \cdots \mathrm{HN}$ bonds. The results indicate that the stabilization provided by such interactions increases on going from $3_{10}$-helix to $\alpha$-helix to $\beta$-sheet.
\end{abstract}

\section{Introduction}

Site-directed mutagenesis has been successfully used to probe participation of individual residues in binding, catalytic action, folding, and stabilization of proteins. ${ }^{1,2}$ However, the interpretation of the apparent energy of

(1) Fersht, A. R.; Matoushek, A.; Serrano, L.J . Mol. Biol. 1992, 224, 771. Fersht, A. R.; Serrano, L. Curr. Opin. Struct. Biol. 1993, 3, 75. Fersht, A. R. Curr. Opin. Struct. Biol. 1995, 5, 79.

(2) Chakrabartty, A.; Baldwin, R. L. Adv. Protein Chem. 1995, 46, 141. Smith, C. K.; Regan, L. Acc. Chem. Res. 1997, 30, 153. interaction $\Delta \Delta \mathrm{G}_{\text {app }}$, i.e., the change in free energy of equilibrium or activation caused by a single amino acid substitution, is often difficult due to the uncertainties concerning solvation, mutant's structural integrity, and unfol ded-state ensemble. ${ }^{3}$ An example is unnatural amino acid mutagenesis aiming at evaluation of the role of backbone-backbone $\mathrm{C}=\mathrm{O} \cdots \mathrm{HN}$ bonds in stabilization of the native structure, ${ }^{4-8}$ still a controversial issue, ${ }^{9,10}$ and

(3) Fersht, A. Structure and Mechanism in Protein Science; W. H. Freeman \& Co.: New York, 1999; Chapter 15. 
in molecular recognition. ${ }^{11-19}$ In this method, incorporation of an $\alpha$-hydroxy acid into the polypeptide chain replaces the peptide linkage $\mathrm{NH}$ group with the ester linkage $0.20,21$ Some results of such mutations appear consistent with the data suggesting that the strength of backbone-backbone $\mathrm{H}$-bonds increases on going from turn or $3_{10}$-helix to $\alpha$-helix to $\beta$-sheet:22 for instance, the substitutions in $\mathrm{N}-\mathrm{H}$-acceptor peptide bonds are desta-

(4) (a) Koh, J . T.; Cornish, V. W.; Schultz, P. G. Biochemistry 1997 36, 11314. (b) Chapman, E.; Thorson, J . S.; Schultz, P. G. J . Am. Chem. Soc. 1997, 119, 7151. (c) Śhin, I.; Ting, A. Y.; Schultz, P. G. J. Am. Chem. Soc. 1997, 119, 12667.

(5) Beligere, G. S.; Dawson, P. E. J . Am. Chem. Soc. 2000, 122, 120.

(6) Nakhle, B. M.; Silinski, P.; Fitzgerald, M. C. J . Am. Chem. Soc. 2000, 122, 8105. Wales, T. E.; Fitzgerald, M. C. J. Am. Chem. Soc. $2001,123,7709$

(7) Low, D. W.; Hill, M. G. J . Am. Chem. Soc. 2000, 122, 11039.

(8) Seebach, D.; Mahajan, Y. R.; Senthilkumar, R.; Rueping, M.; J aun, B. J . Chem. Soc., Chem. Commun. 2002, 1598.

(9) Creighton, T. Curr. Opin. Chem. Biol. 1991, 1, 5. Murphy, K. P.; Gill, S. J .J . Mol. Biol. 1991, 222, 699. Privalov, P. L.; Makhatadze, G. I. J . Mol. Biol. 1993, 232, 660. Myers, J . K.; Pace, C. N. Biophys. J . 1996, 71, 2033.

(10) Dill, K. A. Biochemistry 1990, 29, 7133. Yang, A. S.; Honig, B. J . Mol. Biol. 1995, 252, 351.

(11) Bramson, N. H.; Thomas, N. E.; Kaiser, E. T. J . Biol. Chem. 1985, 260, 15452. Thomas, N. E.; Bramson, H. N.; Miller, W. T.; Kaiser, E. T. Biochemistry 1987, 26, 4461.

(12) Bartlett, P. A.; Marlowe, C. K. Science 1987, 235, 569. Morgan, B. P.; Scholtz, J . M.; Ballinger, M. D.; Zipkin, I. D.; Bartlett, P. A. J . Am. Chem. Soc. 1991, 113, 297.

(13) Groeger, C.; Wenzel, H. R.; Tschesche, H. Int. J . PeptideProtein Res. 1994, 44, 166

(14) Searle, M. S.; Sharman, G. J .; Groves, P.; Benhamu, B. Beauregard, D. A.; Westwell, M. S.; Dancer, R. J .; Maguire, A. J .; Try, A. C.; Williams, D. H. J . Chem. Soc., Perkin Trans. 1 1996, 2781

(15) Lu, W.; Qasim, M. A.; Laskowski, M., J r.; Kent, S. B. H. Biochemistry 1997, 36, 673 .

(16) (a) Lu, W.; Randal, M.; Kossiakoff, A.; Kent, S. B. H. Chem. Biol. 1999, 6, 419. (b) Lu, W.-Y.; Starovasnik, M. A.; Dwyer, J . J .; Kossiakoff, A. A.; Kent, S. B. H.; Lu, W. Biochemistry 2000, 39, 3575.

(17) Baca, M.; Kent, S. B. H. Tetrahedron 2000, 56, 9503.

(18) Trauger, J. W.; Kohli, R. M.; Walsh, C. T. Biochemi stry 2001, 40, 7092.

(19) McComas, C. C.; Crowley, B. M.; Boger, D. L. J . Am. Chem. Soc. 2003, 125, 9314.

(20) For the effect of a single amide-to-ester replacement on ion channel function, see: England, P. M.; Zhang, Y.; Dougherty, D. A.; Lester, H. A. Cell 1999, 96, 89. J ude, A. R.; Providence, L. L. Schmutzer, S. E.; Shobana, S.; Greathouse, D. V.; Andersen, O.; Koeppe, R. E., II. Biochemistry 2001, 40, 1460.

(21) F or a general review of the applications of the unnatural amino acid mutagenesis, see: Dougherty, D. A. Curr. Opin. Chem. Biol. 2000, 4,645

(22) The ${ }^{3 \mathrm{~h}} \mathrm{NiCj}$ interactions across those bonds, reported to correlate with hydrogen bond distances, isotropic $\mathrm{N}_{\mathrm{i}} \mathrm{-H}$ chemical shifts, and ${ }^{11} \mathrm{NiC}_{\mathrm{Ni}}$ couplings, tend to be greater for $\beta$-sheet $\mathrm{H}$-bonds than for $\alpha$-helix $\mathrm{H}$-bonds, and have not been observed in 310 -helices (Cordier, $\mathrm{F}$. Grzesiek, S. J. Am. Chem. Soc. 1999, 121, 1601. Cornilescu, G.; Hu, J.-S.; Bax, A. J. Am. Chem. Soc. 1999, 121, 2949. Cornilescu, G. Ramirez, B. E.; Frank, M. K.; Clore, G. M.; Gronenborn, A. M.; Bax, A. J . Am. Chem. Soc. 1999, 121, 6275. J uranić, N.; Macura, S. J . Am. Chem. Soc. 2001, 123, 4099. J uranić, N.; Moncrieffe, M. C.; Likić, V. A.; Prendergrast, F. G.; Macura, S. J. Am. Chem. Soc. 2002, 124 14221). This is in accord (b) with early conclusions of the surveys of $\mathrm{H}$-bonding geometry in high-resolution crystal structures of proteins (Baker, E. N.; Hubbard, R. E. Prog. Biophys. Mol. Biol. 1984, 44, 97); (c) with trends in amide I and III band shifts in IR (cf. Kubelka, J.; Keiderling, T. A. J. Am. Chem. Soc. 2001, 123, 12048); (d) and with the results of thermodynamic analyses of proteins (Wintrode, P. L.; Makhatadze, G. I.; Privalov, P. L. Proteins: Struct., Funct., Genet. 1994, 18, 2). (e) The opposite conclusion has been reached in the studies of $\mathrm{D} / \mathrm{H}$ amide isotope effect which is most significant in $\alpha$-helical proteins, weaker for $\alpha / \beta$-, and negligible for all $\beta$-proteins: Khare, D.; Alexander, P.; Orban, J . Biochemistry 1999, 38, 3918. Shi, Z.; Krantz, B. A.; Kallenbach, N.; Sosnick, T. R. Biochemistry 2002, 41, 2120. It has been pointed out, however, that $\mathrm{D} / \mathrm{H}$ fractionation at protein backbone amides reflects restrictions or enhancements of specific vibrational modes by the $\mathrm{H}$-bond $3 \mathrm{D}$-environment that is, in general, $\mathrm{H}$-bonding geometry, and is largely independent of $\mathrm{H}$-bonding strength: Bowers, P. M.; Klevit, R. E. J . Am. Chem. Soc. 2000, 122 1030. bilizing by $0.9 \mathrm{kcal} \mathrm{mol}^{-1}$ in the $\alpha$-helix $39-50$ in T4 lysozyme, and by $1.5-2.5 \mathrm{kcal} \mathrm{mol}^{-1}$ in the antiparallel $\beta$-barrel of Staphylococcal nuclease. ${ }^{4}$ Unfortunately, the experimental $\Delta \Delta \mathrm{G}^{\circ}$ determined upon deleting or perturbing one member of a hydrogen bond pair does not provide a direct measure of the strength of a hydrogen bond. Rather, the $\Delta \Delta G^{\circ}$ reflects the difference between the amide interactions in the folded and unfolded states, and the ester interactions in the folded and unfolded states, all in water. For the enzyme-inhibitor complexes, the apparent free-energy change $\Delta \Delta \mathrm{G}$ amide-ester associated with the $\mathrm{NH} \rightarrow \mathrm{O}$ substitution is proposed to be affected by loss of the backbone $\mathrm{H}$-bond, the differential dehydration energy of inhibitors in the free form, and the electrostatic and van der Waals interaction between the two oxygen atoms in the $\mathrm{H}$-bond depleted complex: ${ }^{15,16}$ $\Delta \Delta \mathrm{G}^{\text {amide } \rightarrow \text { ester }}=\Delta \mathrm{G}^{\mathrm{O} \cdots \mathrm{O}}+\left(\Delta \mathrm{G}^{\text {amide }}\right.$ solvation $\left.-\Delta \mathrm{G}^{\text {ester }}{ }_{\text {solvation }}\right)$ $-\Delta \Delta \mathrm{G}^{\mathrm{H}-\text { bond }}$. In either case, a number of assumptions concerning the degree of solvent accessibility at the site of mutation, solvation energies, energies of other dipoledipole interactions in the local protein environment, etc. are required to interpret the magnitude of the destabilization effect. ${ }^{4 a}$ So far, there is no conclusive evidence relating to such assumptions. For instance, the $\mathrm{NH} \rightarrow \mathrm{O}$ and $\mathrm{NH} \rightarrow \mathrm{CH}_{2}$ substitutions were found to have the same effect on stability of the BPTI complex with trypsin, ${ }^{13}$ hence neither $\Delta G^{0 \cdots 0}$ nor $\left(\Delta G^{\text {amide }}{ }_{\text {solvation }}-\right.$ $\Delta G^{\text {ester }}$ solvation) contribution seemed here significant. ${ }^{15,16}$ The same conclusion in regard to $\Delta \mathrm{G}^{\mathrm{O} \cdots \mathrm{O}}$ was reached by comparing mutations at the $\mathrm{N}$ and $\mathrm{C}$ termini of $\alpha$-helix 39-50 in T4 Iysozyme. ${ }^{4 a}$ On the other hand, there is a considerable difference in the effects of the $\mathrm{NH} \rightarrow \mathrm{O}$ and $\mathrm{NH} \rightarrow \mathrm{CH}_{2}$ substitutions on the complexes of thermolysin with phosphorus-containing peptide analogues, ${ }^{12}$ and vancomycin with $A C^{D} A^{D} A,{ }^{19}$ and it was proposed that it is the $0 \cdots \mathrm{O}$ repulsion, not the $\mathrm{H}$-bond loss, that is responsible for the larger share of the reduced binding affinity. ${ }^{19}$ Furthermore, the free-energy perturbation calculations indicated that reduction in the solvation energy can be a major factor in the case of thermolysin complexes. ${ }^{23}$ The need to devel op a better understanding of the effects of the Ala $\rightarrow$ Lac substitution is underscored by a number of "anomalous" results: the destabilization effect can be greater for the mutation at the $\mathrm{N}-\mathrm{H}$ acceptor bond than at the $\mathrm{N}-\mathrm{H}$-donor bond $(0.9 \mathrm{kcal}$ $\mathrm{mol}^{-1}$ at $\mathrm{N}$-terminus of $\alpha$-helix $39-50$ in T4 lysozyme, Leu-39, but only $0.7 \mathrm{kcal} \mathrm{mol}^{-1}$ at C-terminus of the same T4 Iysozyme helix, Ile-50), ${ }^{4 a}$ or even greater than at the $\mathrm{N}-\mathrm{H}$-acceptor/donor bond $\left(2.5 \mathrm{kcal} \mathrm{mol}^{-1}\right.$ at Leu-14 of Staphylococcal nuclease, but only $1.7 \mathrm{kcal} \mathrm{mol}^{-1}$ at Ser44 in the middle of $\alpha$-helix 39-50 in T4 Iysozyme), ${ }^{4 a b}$ while the $\mathrm{NH} \rightarrow \mathrm{O}$ substitution at the $\mathrm{P} 2$ position of egl in c unexpectedly leads to enhancement in both stability and binding to several serine proteases. ${ }^{16 a}$

One way to circumvent many of the difficulties of the above method is to examine the effect of a single-site substitution by quantum mechanical methods. Ab initio MO or density functional theory studies will allow separation of the continuous dielectric and specific solvation effects, and remove the unfol ded-state ensemble from the thermodynamic cycle by estimating the strength

(23) Bash, P. A.; Kollman, P. A.; Singh, U. C.; Brown, F. K.; Langridge, R. Science 1987, 235, 574. Mertz, K. M.; Kollman, P. K. J . Am. Chem. Soc. 1989, 111, 5649. 
of a given bonding interaction via an isodesmic reaction scheme. ${ }^{24}$ Furthermore, such studies might provide detailed information about the possible distortions of the wild-type structure that can be expected as a result of a single-site mutation. ${ }^{25}$ In this paper, we describe an application of such a quantum chemical approach to the $\alpha$-amino acid $\rightarrow \alpha$-hydroxy acid substitutions.

\section{Computational Methods}

In the first part of the study, a number of $\mathrm{N}$-acetyl polyalanyl amides $\left(\mathrm{ACA}_{n} \mathrm{NH}_{2}\right)$ were fully optimized in the conformations corresponding to the $3_{10}-(n=7,9), 4_{13}-(\alpha$-helix, $\mathrm{n}=10,14$ ), and "hybrid" $\kappa$-helix (an $\alpha$-helix with the C terminal $3_{10}$-turn, often encountered in proteins, ${ }^{26} \mathrm{n}=9$ ) as well as the hairpin and triple-stranded antiparallel $\beta$-sheets (type I turns $\beta \alpha \alpha \epsilon, \mathrm{n}=6,9,10$ ), at the HF/3-21G level of the theory. This method was recently reported by Topol et al. to yield satisfactory geometries of the local minima of $\mathrm{N}$-formyl polyalanine amides such as $3_{10}$ and $4_{13}(\alpha)$ helices. ${ }^{27}$ The protocol involved folding of the polyalanyl chain into the starting conformer using the standard $\varphi_{i}$ and $\psi_{i}$ values and subsequently an unconstrained optimization. As was reported earlier, ${ }^{27}$ only in the case of some helical minima it was necessary to initially constrain the structure to preserve the desired $\mathrm{H}$-bonding pattern through the early stage of optimization. ${ }^{28,29}$ Thus, all the final helical and hairpin structures reported here were fully relaxed, and all the searches were completed by the default convergence criteria of Gaussian98. In the second part of the study, to derive planar antiparallel and parallel $\beta$-sheet models, the protocol of Kubelka and Keiderling was used, 22c that is $\mathrm{N}$-acetyl polyalanyl methylamides $\left(\mathrm{ACA}_{n} \mathrm{NHCH}_{3}, \mathrm{n}=2,3\right)$ were folded into extended strands using $\varphi_{\mathrm{i}}=-138.6^{\circ}$ and $\psi_{\mathrm{i}}=134.5^{\circ}$ (the values from the crystal structure of $\beta$-sheet poly-L-alanine, for the planar antiparallel model) and $\varphi_{\mathrm{i}}=-119^{\circ}$ and $\psi_{\mathrm{i}}=113^{\circ}$ (thestandard values for the planar parallel model), and partially optimized with the $\varphi_{\mathrm{i}}$ and $\psi_{\mathrm{i}}$ torsional angles constrained to the above values. The strands were assembled into binary and tertiary complexes which were partially optimized, that is the $\varphi_{\mathrm{i}}$ and $\psi_{\mathrm{i}}$ angles were kept frozen at the initial level.

Subsequently, each residue of every "native" model structure was substituted, one at the time, with L-lactic acid, i.e., the backbone $\mathrm{NH}$ group was replaced by the $\mathrm{O}$ group. The

(24) Hehre, W. J .; Ditchfield, R.; Radom, L.; Pople, J . A. J . Am. Chem. Soc. 1970, 92, 4796. See also: Wiberg, K. B. Acc. Chem. Res. 1999, 32, 922.

(25) For the structural studies (X-ray) of depsipeptides, see: (a) Valle, G.; Bardi, R.; Piazzesi, A. M.; Crisma, M.; Toniolo, C.; Cavicchioni, G.; Uma, K.; Balaram, P. Biopolymers 1991, 31, 1669. (b) Crisma, M.; Valle, G.; Bonora, G. M.; Toniolo, C.; Cavicchioni, G. Int. J. PeptideProtein Res. 1993, 41, 553. (c) Ohyama, T.; Oku, H.; Hiroki, A.; Maekawa, Y.; Yoshida, M.; Katakai, R. Biopolymers 2000, 54, 375. (d) Ohyama, T.; Oku, H.; Hiroki, A.; Yoshida, M.; Katakai, R. Biopolymers 2001, 58, 636. (e) Karle, I. L.; Das, C.; Balaram, P. Biopolymers 2001, 59, 276. (f) Arawinda, S.; Shamala, N.; Das, C.; Balaram, P. Biopolymers 2002, 64, 255. (g) Peggion, C.; Barazza, A.; Formaggio, F.; Crisma, M.; Toniolo, C.; Villa, M.; Tomasini, C.; Mayrhofer, H.; Pöchlauer, P.; Kaptein, B.; Broxterman, Q. B.J . Chem. Soc., Perkin Trans. 2 2002, 644.

(26) Barlow, D. J .; Thornton, J. M. J . Mol. Biol. 1988, 201, 601.

(27) Topol, I. A.; Burt, S. K.; Deretey, E.; Tang, T.-H.; Perczel, A.; Rashin, A.; Csizmadia, I. G. J . Am. Chem. Soc. 2001, 123, 6054.

(28) For the most recent full optimizations of the secondary structure models, see: (a) Perczel, A.; J àkli, I.; Csizmadia, I. G. Chem. Eur. J . 2003, 9, 5332. (b) Wieczorek, R.; Dannenberg, J . J . J . Am. Chem. Soc. 2003, 125, 8124. (c) Bour, P.; Kubelka, J .; Keiderling, T. A. Biopolymers 2002, 65, 45.

(29) For a DFT study of polyglycine helix models based on the repeating unit approach, see: Wu, Y.-D.; Zhao, Y.-L. J . Am. Chem. Soc. 2001, 123, 5313. (b) For the studies of secondary structure models employing periodic boundary conditions, see: Improta, R.; Barone, V.; Kudin, K. N.; Scuseria, G. J. Am. Chem. Soc. 2001, 123, 3311. Rossmeisl, J .; Hinneman, B.; J acobsen, K. W.; Nørskov, J . J . Chem. Phys. 2003, 118, 9783. SCHEME 1. Concept of Isodesmic Group-Transfer
Reaction Applied to the Ala $\rightarrow$ Lac Mutagenesis ${ }^{\mathrm{a}}$

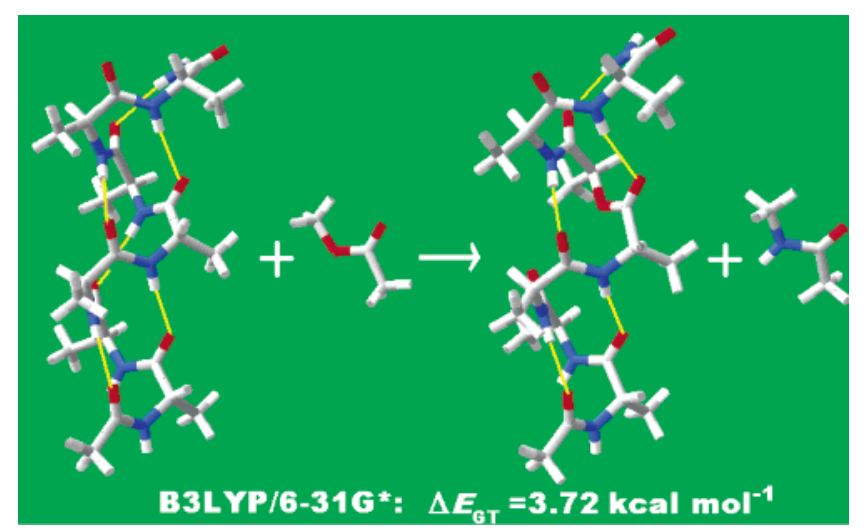

a The scheme presents a hypothetical reaction of $\mathrm{AcA}_{7} \mathrm{NH}_{2}$ in $3_{10}$-helix conformation I with methyl acetate which yields $3_{10}-$ helical depsipeptide I5 and $\mathrm{N}$-methyl acetamide. The mutation site is $m=5$ (the residue and peptide bond numbering begins at the $\mathrm{N}$-terminus at the bottom of the diagram). Since the type and number of covalent bonds in the educts and the products are the same, and the chain conformation is roughly preserved in the depsipeptide, the major effect on the potential energy is expected to be due to loss of one backbone-backbone $\mathrm{H}$-bond $(\mathrm{O} 2 \cdots \mathrm{NH} 5)$ and weakening of another one $(\mathrm{O} 4 \cdots \mathrm{NH} 7)$, and $02 \cdots \mathrm{O} 5 \mathrm{~L}$ repulsion.

resulting mutant structures were again optimized: full optimizations were performed in the case of the helical and hairpin conformers, and partial optimizations in the case of the multistranded $\beta$-sheet models; that is, the $\varphi_{\mathrm{i}}$ and $\psi_{\mathrm{i}}$ torsion angles continued to be constrained to the initial values.

The group-transfer energies $\Delta \mathrm{E}_{\mathrm{GT}}$ for the above substitutions were obtained as heats of the isodesmic reactions: $A_{C A} A_{n}$ $\mathrm{NHR}+\mathrm{AcOMe} \rightarrow \mathrm{AcA}_{x} \mathrm{LacA}_{y} \mathrm{NHR}+\mathrm{AcNHMe}\left(\mathrm{R}=\mathrm{H}, \mathrm{CH}_{3}\right)$. The concept of such a reaction as it applies here is illustrated in Scheme 1.

To establish how reliable are the HF/3-21G group-transfer energies, a number of wild-type structures and their depsipeptide mutants were reoptimized at the B 3L YP/6-31G* level (in addition, a few helical conformers were reoptimized at the HF/ 6-31G** and B3L YP/D95** levels). In each case, the optimization was continued untill the default convergence criteria were fully met. All of the calculations were performed using parallel version of Gaussian98 Revision A.7 installed on Sun Enterprise 4500 High-Performance Server, and Gaussian98 Revision A.11.2. ${ }^{30}$

\section{Results and Discussion}

a. Ala $\rightarrow$ Lac Substitutions in Helix Conformers. The group-transfer energies $\Delta \mathrm{E}_{\mathrm{GT}}$ for mutations of the fully optimized helical conformers are summarized in Table 1, and the representative native structures are shown in Chart 1 . These reactions are endothermic

(30) Frisch, M. J .; Trucks, G. W.; Schlegel, H. B.; Scuseria, G. E.; Robb, M. A.; Cheeseman, J . R.; Zakrzewski, V. G.; Montgomery, J . A., J r.; Stratmann, R. E.; Burant, J . C.; Dapprich, S.; Millam, J. M.; Daniels, A. D.; Kudin, K. N.; Strain, M. C.; Farkas, O.; Tomasi, J .; Barone, V.; Cossi, M.; Cammi, R.; Mennucci, B.; Pomelli, C.; Adamo, C.; Clifford, S.; Ochterski, J .; Petersson, G. A.; Ayala, P. Y.; Cui, Q.; Morokuma, K.; Rega, N.; Salvador, S.; Dannenberg, J . J .; Malick, D. K.; Rabuck, A. D.; Raghavachari, K.; Foresman, J . B.; Cioslowski, J .; Ortiz, J. V.; Baboul, A. G.; Stefanov, B. B.; Liu, G.; Liashenko, A.; Piskorz, P.; Komaromi, I .; Gomperts, R.; Martin, R. L.; Fox, D. J .; Keith, T.; Al-Laham, M. A.; Peng, C. Y.; Nanayakkara, A.; Challacombe, M.; P. Gill, P. M. W.; J ohnson, B.; Chen, W.; Wong, M. W.; Andres, J . L.; Gonzalez, C.; Head-Gordon, M.; Replogle, E. S.; Pople, J . A. Gaussian, Inc., Pittsburgh, PA, 2001. 
TABLE 1. Group-Transfer Energies $\Delta E_{\mathrm{GT}}\left(\mathrm{kcal} \mathrm{mol}^{-1}\right)$ for $\mathrm{m}$ Ala $\rightarrow$ Lac Mutations of $\mathrm{N}$-acetyl Polyalanine Amides from the Isodesmic Reactions $\mathrm{AcA}_{\mathbf{n}} \mathbf{N H}_{2}+$ AcOMe $\rightarrow \mathrm{ACA}_{x} \mathrm{LaCA}_{y} \mathrm{NH}_{2}+\mathbf{A c N H M e}$ (m Denotes the Mutation Site) ${ }^{a}$

\begin{tabular}{|c|c|c|c|c|c|c|c|c|}
\hline \multirow[t]{2}{*}{$\mathrm{m}$} & \multicolumn{2}{|c|}{310 -helix } & \multicolumn{2}{|c|}{$\alpha$-helix } & \multirow{2}{*}{$\frac{\kappa \text {-helix }}{\mathbf{V}}$} & \multirow{2}{*}{$\frac{\text { hairpin }}{\text { VI }}$} & \multicolumn{2}{|c|}{$\begin{array}{l}\text { triple-stranded } \\
\text { hairpin } \beta \text {-sheet }\end{array}$} \\
\hline & I & II & III & IV & & & VII & VIII \\
\hline 1 & 1.7 & 1.9 & 3.0 & 3.3 & 2.9 & 8.8 & 9.1 & 8.9 \\
\hline 2 & 1.6 & 1.8 & 1.8 & 2.2 & 1.8 & 13.5 & 12.6 & 12.4 \\
\hline 3 & 3.7* & $2.6^{*}$ & 3.1 & 3.5 & 3.0 & -0.9 & -2.0 & -0.6 \\
\hline 4 & 7.6 & 8.3 & 5.0 & 5.9 & 5.0 & 0.3 & 0.2 & 0.6 \\
\hline 5 & 7.3 & 8.2 & $5.7^{*}$ & 7.1* & $5.5^{*}$ & 4.8* & $2.6 *$ & $6.1^{*}$ \\
\hline 6 & 7.2 & 8.4 & 8.2 & 9.9 & 7.7 & 9.0 & 13.2 & 14.8 \\
\hline 7 & 4.0 & 8.1 & 9.8 & 11.4 & 8.7 & & $6.5^{*}$ & $2.7^{*}$ \\
\hline 8 & & 7.6 & 9.4 & 11.6 & 9.9 & & 0.6 & 0.4 \\
\hline 9 & & 4.6 & 5.7 & 11.7 & 9.7 & & 6.9 & 7.1 \\
\hline 10 & & & 5.2 & 11.2 & 6.4 & & & 9.1 \\
\hline 11 & & & & 11.4 & & & & \\
\hline 12 & & & & 10.4 & & & & \\
\hline 13 & & & & 6.5 & & & & \\
\hline 14 & & & & 6.4 & & & & \\
\hline
\end{tabular}

a Asterisks indicate that the $\mathrm{H}$-bonding pattern of the "wildtype" structure is not preserved in the depsipeptide mutant and/ or a compensating donor-acceptor interaction is introduced.

$\left(\Delta \mathrm{E}_{\mathrm{GT}}>0\right)$ that is the effect of mutation is, as expected, destabilizing. In the case of the endo peptide bonds in $\mathrm{AcA}_{3} \mathrm{NHCH}_{3}$ constrained into a single $\alpha$-helix turn, IX, the substitutions are thermoneutral; i.e., the $\mathrm{NH}$ and $\mathrm{O}$ interactions with the immediate mol ecular environment appear equivalent both in N,O-methyl acetyl derivatives and in the helical conformers of the peptide chain. ${ }^{31}$

Examination of the integrity of $\mathrm{H}$-bonding patterns and $\psi_{\mathrm{i}}, \varphi_{\mathrm{i}}$ distribution in the depsipeptide mutants reveals a wide range of distortions of the "wild-type" structure. On one hand, the Ala $\rightarrow$ Lac substitution often causes just a small "localized" change of the backbone torsional angles so as to be nearly isosteric; see I5 in Scheme 1. On the other hand, this substitution can also produce a major conformational change associated with a formation of an additional, compensatory backbone-backbone interaction.

In the case of the helical structures, such distortions involve transitions from $\mathrm{i}, \mathrm{i}+3$ to $\mathrm{i}, \mathrm{i}+4 \mathrm{H}$-bonding in the first turn of the $3_{10}$-helix as a result of mutation at the site $m=3$ (entries $\mathbf{I 3}$ and $\mathbf{I I} \mathbf{3}$ in Table 1 ) and transitions from $\mathrm{i}, \mathrm{i}+4$ to $\mathrm{i}, \mathrm{i}+3 \mathrm{H}$-bonding in the first turn of the $\alpha$-helix as a result of mutation at the site $\mathrm{m}=5$ (entries III5, IV5, and V5 in Table 1). The latter transition is reminiscent of the appearance of a $3{ }_{10}$-helical segment at the connective part between the peptide and the depsipeptide units in the crystal structure of a pentadecadepsipeptide $\operatorname{Boc}\left(\mathrm{L}_{2} \mathrm{~A}\right)_{2}\left(\mathrm{~L}_{2} \mathrm{Lac}\right)_{3} \mathrm{OEt}$ reported by Katakai et al. ${ }^{25 \mathrm{c}}$ and at the mutation sites in depsipeptides BocVALAibVLacLAibVALOMe and BocVALAibVLacLAibVLOMe reported by Karle, Das, and Balaram. ${ }^{25 e}$ These transitions can be conveniently depicted in the $\mathrm{H}$-bonding schemes in Chart 1: (i) in the diagram $\mathrm{A}$, the $\mathrm{N}$-terminal acetyl $\mathrm{O}$ (no label) would bond to $\mathrm{N} 4 \mathrm{H}$ after the removal of $\mathrm{N3H}$ (mutation $\mathrm{m}=3$,

(31) IX is $\mathrm{ACA}_{3} \mathrm{NHCH}_{3}$ folded into a single turn of the $\alpha$-hel ix using $\varphi_{\mathrm{i}}=-63.4^{\circ}$ and $\psi_{\mathrm{i}}=-37.6^{\circ}$, and partially optimized with all the $\varphi_{\mathrm{i}}$ and $\psi_{\mathrm{i}}$ torsional angles constrained to the above values. The $\Delta \mathrm{E}_{\mathrm{GT}}$ 's for IX2, IX3 are $-0.19,0.63 \mathrm{kcal} \mathrm{mol}^{-1}(\mathrm{HF} / 3-21 \mathrm{G})$, and $-1.08,-0.29$ kcal mol ${ }^{-1}$ (B3LYP/6-31G*).
CHART 1. Three Types of Right-Handed Helices Examined in the Present Study: (A) $3_{10}-\mathrm{Helix}$ AcA9 $\mathrm{NH}_{2}$ II; (B) $\kappa$-Helix AcA9NH $\mathrm{NH}_{2}$; (C) $\alpha$-Helix $\mathrm{ACA}_{10} \mathrm{NH}_{2}$ III

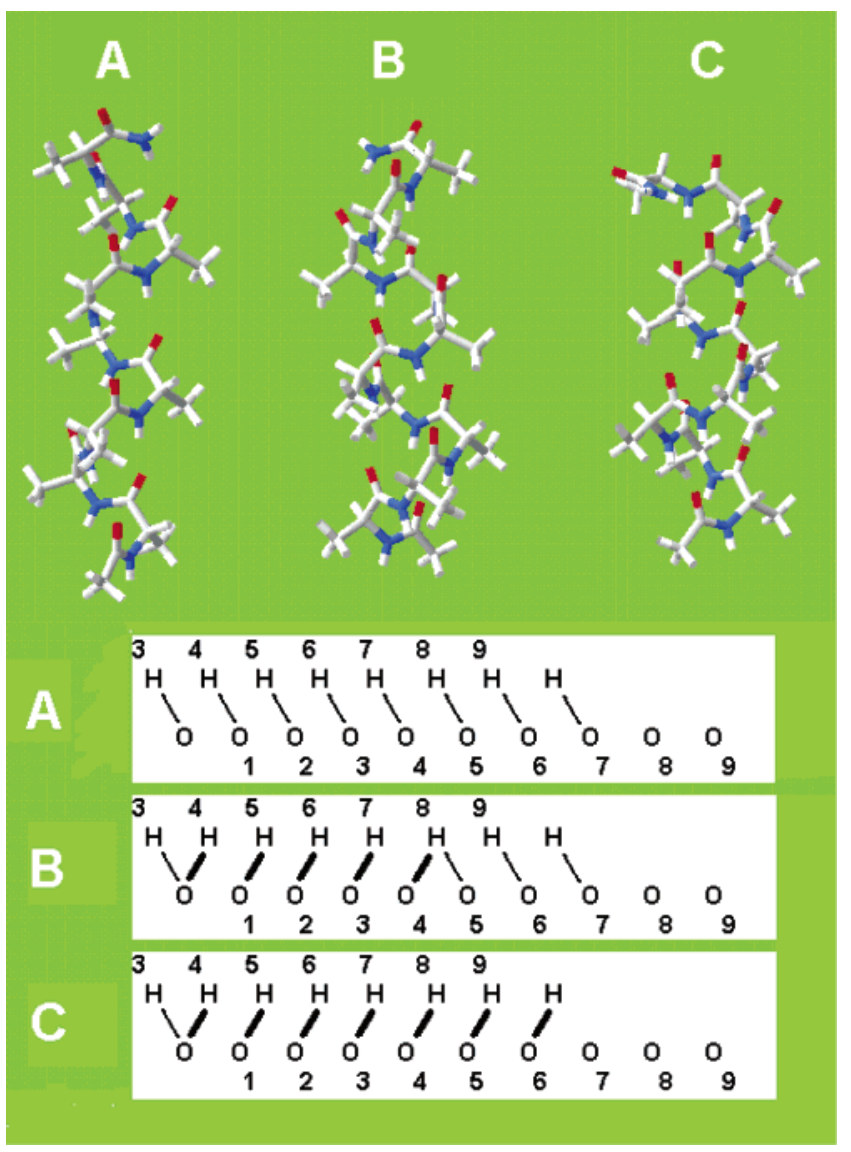

a The pattern of the backbone-backbone $\mathrm{H}$-bonding in each helix is shown in the convention of Topol et al. ${ }^{27}$ The residues (mutation sites) are numbered beginning at the $\mathrm{N}$-terminus at the bottom of the diagram.

followed by the transition from i, i +3 to $\mathrm{i}, \mathrm{i}+4$ $\mathrm{H}$-bonding), (ii) in the diagrams $\mathrm{B}$ and $\mathrm{C}$, the $\mathrm{O} 1$ atom would bond to $\mathrm{N} 4 \mathrm{H}$ after the removal of $\mathrm{N} 5 \mathrm{H}$ (mutation $m=5$, followed by the transition from $i, i+4$ to $i, i+3$ $\mathrm{H}$-bonding).

The extent of the "localized" conformational distortions is illustrated by the data in Table 2 which lists the backbone torsion angles in $3_{10}$-helix $\mathrm{AcA}_{9} \mathrm{NH}_{2}{ }^{28 \mathrm{c}}$ and its $m=6$ mutant, $A c A_{5} L_{a c A_{3}} N_{2}$, at different levels of theory. In accord with the previous report, ${ }^{27,28 a}$ there is a good agreement between the HF/3-21G and B3LYP/ 6-31G* geometries, with a minor change in the conformations of the terminal residues.

Examination of the molecular geometry of the mutant helices suggests that the main reason for the distortion is the $0 \cdots 0$ repulsion rather than the difference in the amide and ester torsional potentials. The $\mathrm{O} \cdots \mathrm{N}$ separation in helical backbone-backbone $\mathrm{H}$-bonds is uniformly very close to $3.0 \AA$, but the $0 \cdots 0$ separation in depsipeptide $3_{10}$-helices is $3.5-3.7 \AA$, and in $4_{13}$-helices $3.2-3.3$ $\AA$ (HF/3-21G; B3LYP/6-31G* distances are 0.1-0.2 greater). The corresponding distances in the crystal structures are reported to be $3.81(2), 3.87(2) \AA, 25 \mathrm{c}$ and $3.24(2), 3.47(2),{ }^{25 d} 3.1-3.3 \AA,{ }^{25}$ respectively. Thus, the 
TABLE 2. Main-Chain Torsional Angles of $\mathrm{ACA}_{9} \mathrm{NH}_{2}(\mathrm{II})$ and Its Mutant $\mathbf{m}=6$ (II6) in the $3_{10}$-Helix Conformations at Different Levels of the Theory

\begin{tabular}{|c|c|c|c|c|c|c|c|c|}
\hline \multirow{3}{*}{$\begin{array}{c}\text { residue } \\
\text { no. i }\end{array}$} & \multicolumn{4}{|c|}{$\mathrm{HF}$} & \multicolumn{4}{|c|}{ B3LYP } \\
\hline & \multicolumn{2}{|c|}{$3-21 G$} & \multicolumn{2}{|c|}{ 6-31G** } & \multicolumn{2}{|c|}{ 6-31G* } & \multicolumn{2}{|c|}{ D95** } \\
\hline & $\psi_{\mathrm{i}}$ & $\varphi_{\mathrm{i}}$ & $\psi_{\mathrm{i}}$ & $\varphi_{\mathrm{i}}$ & $\psi_{\mathrm{i}}$ & $\varphi_{\mathrm{i}}$ & $\psi_{\mathrm{i}}$ & $\varphi_{\mathrm{i}}$ \\
\hline \multicolumn{9}{|l|}{$\mathrm{AcA}_{9} \mathrm{NH}_{2}$} \\
\hline 1 & -30.2 & -60.6 & -25.6 & -67.2 & -25.1 & -65.7 & -25.3 & -64.5 \\
\hline 2 & -22.7 & -58.7 & -21.7 & -62.2 & -21.6 & -59.3 & -21.9 & -58.4 \\
\hline 3 & -21.8 & -60.2 & -22.0 & -63.1 & -20.8 & -60.9 & -21.5 & -60.1 \\
\hline 4 & -22.1 & -59.8 & -21.8 & -63.2 & -22.3 & -60.0 & -22.0 & -59.5 \\
\hline 5 & -21.5 & -60.3 & -21.5 & -63.4 & -20.7 & -61.5 & -20.7 & -60.7 \\
\hline 6 & -20.6 & -61.4 & -20.8 & -64.0 & -20.3 & -61.8 & -20.6 & -60.9 \\
\hline 7 & -21.2 & -62.5 & -20.6 & -64.7 & -20.6 & -62.6 & -20.4 & -61.8 \\
\hline 8 & -3.0 & -72.9 & -12.9 & -69.8 & -7.7 & -70.2 & -10.8 & -68.1 \\
\hline 9 & 10.5 & -103.5 & 2.2 & -94.1 & 11.3 & -102.6 & 3.3 & -93.8 \\
\hline \multicolumn{9}{|l|}{$\begin{array}{l}\mathrm{AcA}_{3} \mathrm{LaCA}_{3} \mathrm{NH}_{2} \\
\mathrm{~m}=6\end{array}$} \\
\hline 1 & -29.7 & -61.3 & & & -23.9 & -65.7 & & \\
\hline 2 & -26.1 & -58.5 & & & -23.5 & -59.5 & & \\
\hline 3 & -6.1 & -70.2 & & & -12.1 & -67.5 & & \\
\hline 4 & -18.2 & -76.9 & & & -12.4 & -80.4 & & \\
\hline 5 & -33.3 & -52.0 & & & -25.2 & -57.1 & & \\
\hline 6 & -18.4 & -65.0 & & & -18.5 & -66.9 & & \\
\hline 7 & -21.3 & -63.6 & & & -20.1 & -64.3 & & \\
\hline 8 & -3.1 & -72.7 & & & -7.8 & -70.0 & & \\
\hline 9 & 10.5 & -103.6 & & & 10.9 & -102.7 & & \\
\hline
\end{tabular}

depsipeptide helices are somewhat open on one side and compressed on the other, in the manner of selectively solvated $\alpha$-helices in proteins. ${ }^{26}$

The effect of $\mathrm{Ala} \rightarrow \mathrm{Lac}$ substitution on charge distribution in the helices is illustrated in Figure 1 using the difference $\Delta \mathrm{e}$ in $\mathrm{H}$ and $\mathrm{O}$ Mulliken populations in $\mathrm{HN}-$ $\mathrm{C}=\mathrm{O}$ as a measure of charge polarization of the peptide bond. The mutation at the site $\mathrm{m}$ causes, as expected, a decrease in charge polarization of the peptide bonds $m-3$ and $m+3$ (negative deviations in the plots in Figure 1), but it consistently increases the charge polarization of the immediately preceding $\mathrm{m}-1$ bond. The increase is apparently due to the bonding interaction between the peptide and ester linkages, reveal ed by the short $\mathrm{C}_{\mathrm{i}}=\mathrm{O} \cdots \mathrm{C}_{\mathrm{j}}=\mathrm{O}$ contacts $(\mathrm{i}=$ amide, $\mathrm{j}=$ ester; $2.7-$ $2.8 \AA$ rather than the standard $2.9-3.0 \AA, \mathrm{HF} / 3-21 \mathrm{G}) .32,33$ The NBO $E(2)$ energies of the $\mathrm{n}_{\mathrm{O}}(\mathrm{NC}=\mathrm{O})-\pi^{*}(\mathrm{OC}=\mathrm{O})$ interactions in the $3_{10}$-helix are indeed $\sim 2.5-3.0$ times greater than those of the $\mathrm{n}_{0}(\mathrm{NC}=\mathrm{O})-\pi^{*}(\mathrm{NC}=\mathrm{O})$ interactions (e.g., LP(2) O37-BD*(2) C45-O47 in I: $0.90 \mathrm{kcal}$ $\mathrm{mol}^{-1}$; in I5: $\left.2.62 \mathrm{kcal} \mathrm{mol}^{-1}, \mathrm{HF} / 3-21 \mathrm{G}\right){ }^{34}$

Smaller increases in charge polarization of the peptide bonds immediately following the mutation site can probably be attributed to the inductive effect which lowers Lewis basicity of the $\mathrm{C}=\mathrm{O}$ group and increases Lewis acidity of the $\mathrm{N}-\mathrm{H}$ group with the net change which usually is negligible, except for $m=3,10,12$. The data shown in Figure 1 are obtained at the HF/3-21G level, but the changes in charge polarization of the peptide bonds appear to be quite well reproduced at this level of theory. The $\Delta e$ values obtained for the reoptimized structures I, I4, II, and $\mathbf{I I 6}$ are plotted against the

(32) Bent, H. Chem. Rev. 1968, 68, 587

(33) Bürgi, H. B.; Dunitz, J. D. Acc. Chem. Res. 1983, 16, 153. See also: Cieplak, A. S. In Structure Correlation; Dunitz, J . D., Bürgi, H .B., Eds.; Verlag Chemie: Weinheim, 1994; Vol. 1, Chapter 6, pp 205302.

(34) Reed, A. E.; Weinstock, R. B.; Weinhold, F.J . Chem. Phys. 1985, 83, 735. Glendening, E. D.; Reed, A. E.; Carpenter, J . E.; Weinhold, F. NBO Version 3.1. corresponding HF/3-21G values in Figure 2. The anisotropy of charge distribution is exaggerated at the lower levels of theory; nonetheless, the HF/3-21G model is certainly qualitatively useful. ${ }^{27,28 a}$

The data for the mutants with altered backbonebackbone interaction patterns are marked in Table 1 with asterisks. For all the other structures, heat of the substitution reaction is expected to reflect primarily loss of $\mathrm{C}=\mathrm{O} \cdots \mathrm{H}-\mathrm{N}$ bonding. It is therefore quite interesting to see in Table 1 a wide range of the $\Delta \mathrm{E}_{\mathrm{GT}}$ values for the helical polyalanines I-V: (i) $1.7-3.3 \mathrm{kcal} \mathrm{mol}^{-1}$ in the case of substitutions in the bonds that are exclusively $\mathrm{N}-\mathrm{H}$-acceptors, (ii) $4.0-10.4 \mathrm{kcal} \mathrm{mol}^{-1}$ if the peptide bonds are exdusively $\mathrm{N}-\mathrm{H}$-donors, and (iii) $5.0-11.7 \mathrm{kcal}$ $\mathrm{mol}^{-1}$ for the peptide bonds in the middle of the trimeric or longer arrays, i.e., the bonds which are simultaneously $\mathrm{N}-\mathrm{H}$-acceptors and $\mathrm{N}-\mathrm{H}$-donors. There are two noteworthy trends in these data: the increase in $\Delta \mathrm{E}_{\mathrm{GT}}$ with increasing length of the given type helices, i.e., I vs II, or III Vs IV, and the increase in $\Delta \mathrm{E}_{\mathrm{GT}}$ on going from $3_{10^{-}}$ hel ix to $4_{13}$-helix, e.g., II vs III.

b. Multiple Ala $\rightarrow$ Lac Substitutions in the $\alpha-\mathrm{He}-$ lix. The early studies of the sequential polydepsipeptides poly $\left(L_{2} L a c\right)$ by Goodman et al. have suggested that while the substitution certainly decreases peptide helicity, even a multiple substitution does not entirely prevent fol ding into helical structures in nonpolar solvents. ${ }^{35}$ Indeed, several Lac-based depsipeptides were recently found to adopt helical conformations by crystal structure anaIysis. ${ }^{25 c-f}$ Furthermore, chymotrypsin inhibitor $2(\mathrm{Cl} 2)$ has been shown to tolerate, in terms of the folding characteristics, a replacement of an array of four amide bonds that span the length of its $\alpha$-helix with ester bonds. ${ }^{5}$ To model the latter modification, four substitutions were introduced in $\mathrm{N}$-acetyldodecyl amide $\mathbf{X}$

(35) Ingwall, R. T., Goodman, M. Macromolecules, 1974, 7, 598. Wouters, G.; Katakai, R.; Becktel, W. J .; Goodman, M. Macromol ecules $1982,15,31$, and references therein. 

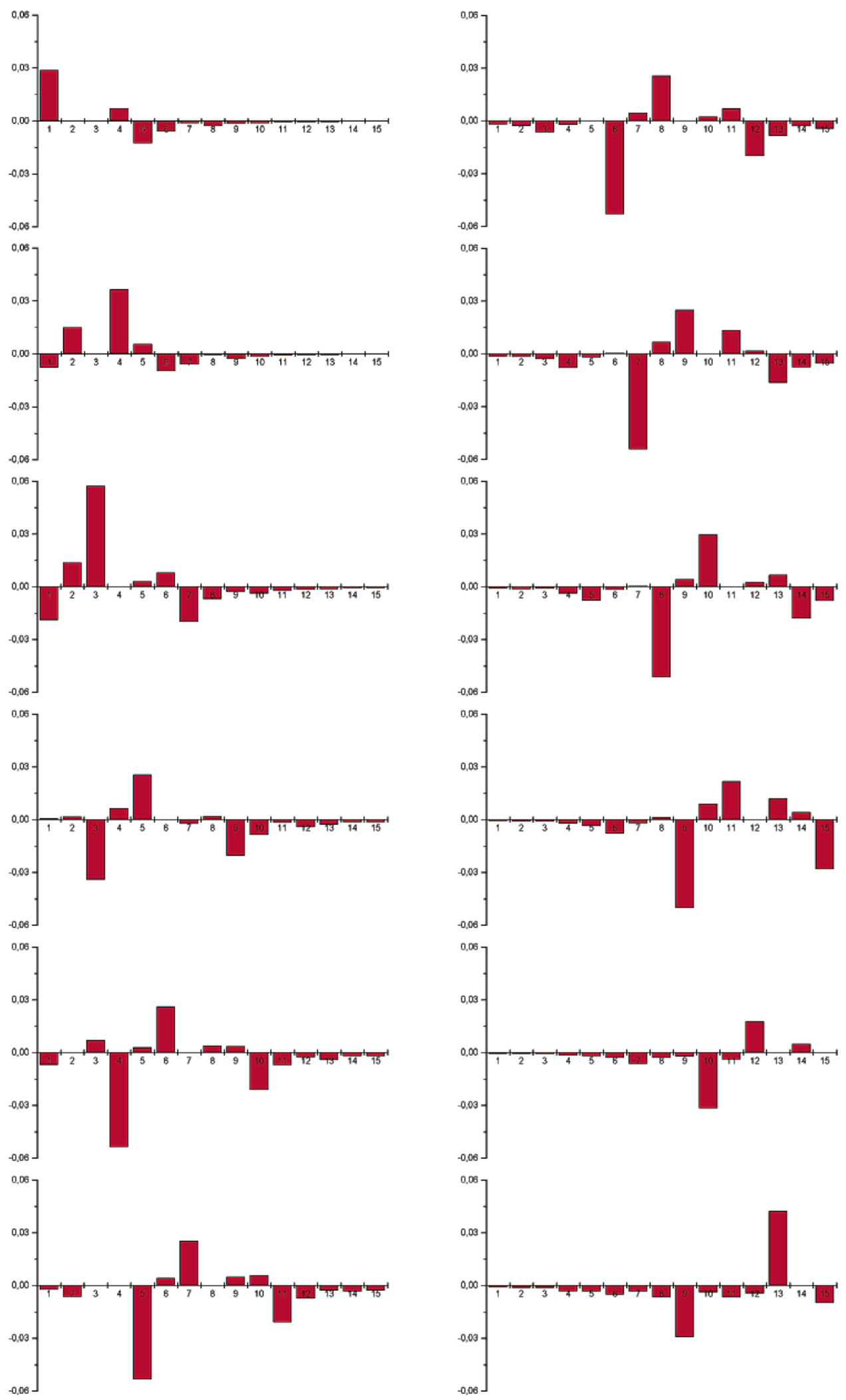

FIGURE 1. Difference $\Delta \Delta \mathrm{e}$ in charge polarization $\Delta \mathrm{e}$ (see text) of the peptide bonds (HF/3-21G) in the depsipeptide mutants IVm and in the "wild-type" hel ix IV,$\Delta \Delta \mathrm{e}=\Delta \mathrm{e}(\mathbf{W T} \mathbf{m})-\Delta \mathrm{e}(\mathbf{W T})(\mathrm{au})$, as a function of the bond location al ong the peptide chain i $(m=2-4,6-14)$. A positive deviation indicates that the peptide bond is more charge-polarized in the mutant.

$\left(\mathrm{AcA}_{12} \mathrm{NH}_{2}\right)$ to yield AcALacA 2 acA $\mathrm{LacA}_{2} \mathrm{LacANH}_{2}$ X2.5.8.11, and $\Delta \mathrm{E}_{\mathrm{GT}}=26.1 \mathrm{kcal} \mathrm{mol}^{-1}$. This value exceeds somewhat the anticipated destabilization effect of $\sim 18$ kcal mol-1 (loss of three $\mathrm{H}$-bonds), but the $4_{13}$-helical conformation is preserved in the quadruple mutant, Chart 2. The $\mathrm{C}=\mathrm{O} \cdots \mathrm{O}$ separations are about $3.1 \AA$. Interestingly, $\mathrm{H}$-bonds in the remaining two amide arrays in the mutant are considerably shorter than the 


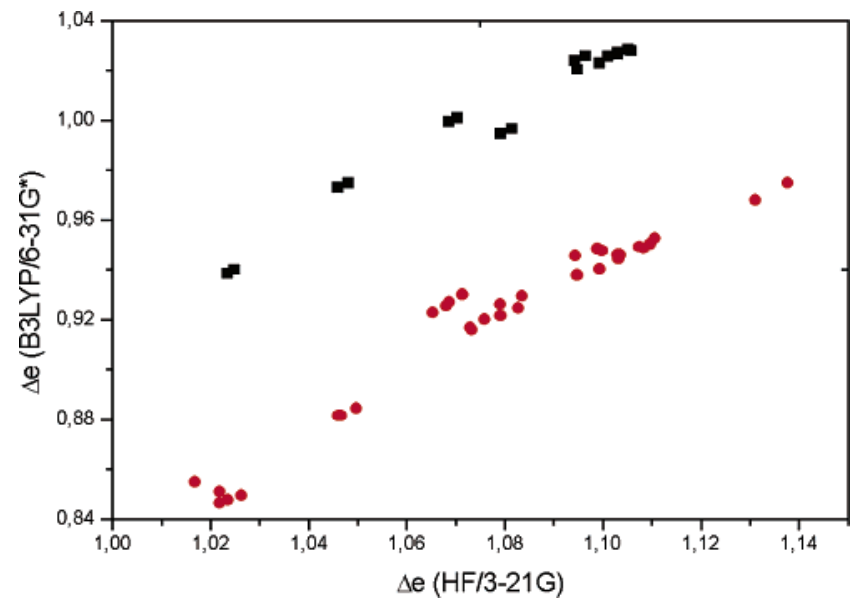

FIGURE 2. Charge polarization of the peptide bonds $\Delta \mathrm{e}$ (au) in 310 -helices I, II, I4, and II $\mathbf{6}$ (two depsi peptide mutants) at different levels of theory (unconstrained optimizations): (A) HF/3-21G values vs the B3LYP/6-31G* values (red circles); (B) $\mathrm{HF} / 3-21 \mathrm{G}$ values vs the HF/6-31G** values (black squares).

CHART 2. ACAL acA $\mathrm{LaCA}_{2} \mathrm{LaCA} \mathrm{LaCANH}_{2}$ X2.5.8.11, a Model for the $\alpha$-Helix in 4-E ster $\mathrm{CI} 2,5$ and the Selected Backbone Interactions ${ }^{a}$

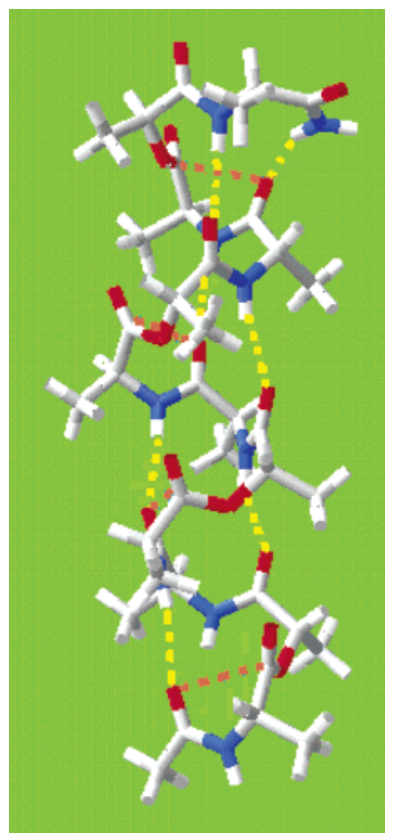

\footnotetext{
a The average $\mathrm{C}=\mathrm{O} \cdots \mathrm{HN}$ bond distance in the array preceding the mutation sites (on the left-hand side of the diagram) is 1.997 $\AA$ compared to $2.107 \AA$ in the parent helix $\mathbf{X}$, in the array following the mutation sites it is $1.954 \AA$, compared to $1.972 \AA$ in $\mathbf{X}$. The average $\mathrm{C}_{\mathrm{i}}=\mathrm{O} \cdots \mathrm{C}_{\mathrm{j}}=\mathrm{O}(\mathrm{i}=$ amide, $\mathrm{j}=$ ester) contact in $\mathbf{X 2 . 5 . 8 . 1 1}$ is $2.765 \AA$ (color-coded orange), compared to the average $2.910 \AA$ in $\mathbf{X}$ ( $\mathrm{i}=$ amide, $\mathrm{j}=$ amide), and $3.091 \AA$ for the alternative ester contact in X2.5.8.11 ( $\mathrm{i}=$ ester, $\mathrm{j}=$ amide).
}

backbone-backbone $\mathrm{H}$-bonds in the parent polyalanyl $\alpha$-helix. The strengthening of these bonds could be due to to the increase in charge polarization of the peptide bonds as described earlier, section $3 a$.

c. Ala $\rightarrow$ Lac Substitutions in Hairpin Conformers. The results for the three fully optimized hairpin models are listed in Table 1 (VI, VII, VIII), and the examples of the structures are given in Chart 3. A wide
CHART 3. The Hairpin-based Triple-stranded $\beta$-sheet Models: the VII5 (A) and VII7 (B) Mutants, and the Selected Backbone Interactions ${ }^{\mathrm{a}}$

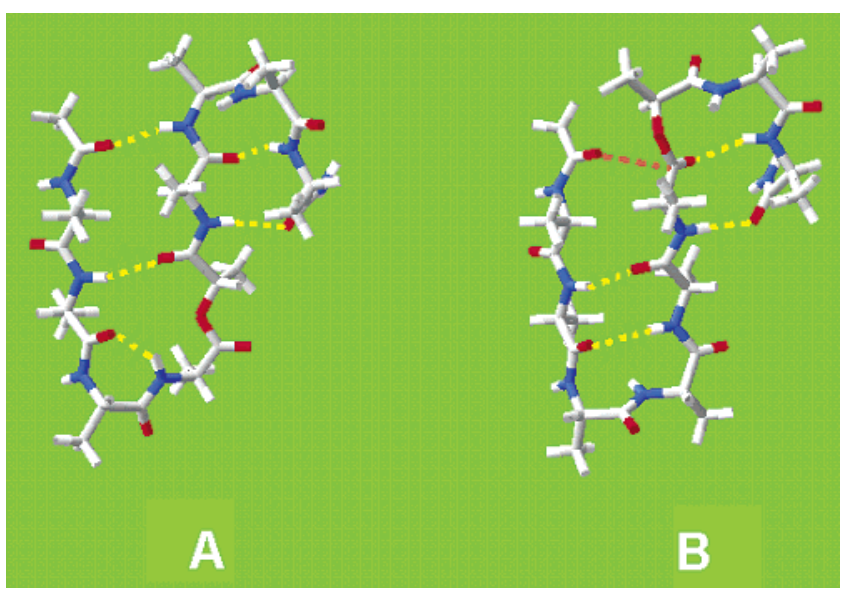

a The numbering of residues (and mutation sites) begins at the $\mathrm{N}$-terminus in the upper left corner of the diagram. The structure VI is obtained by removing three residues from the C-terminus, VIII by adding there one residue. The backbone-backbone $\mathrm{C}=\mathrm{O} \cdots \mathrm{HN}$ bonds are shown in yellow. In $\mathbf{V I I}$ (B), the $\mathrm{C}_{\mathrm{i}}=\mathrm{O} \cdots \mathrm{C}_{\mathrm{j}}=\mathrm{O}$ bonding interaction is shown in orange.

range of the $\Delta \mathrm{E}_{\mathrm{GT}}$ values is also seen in this case. The substitution reactions are nearly thermoneutral in the case of the mid-turn linkages, i.e., peptide groups not involved in $\mathrm{H}$-bonding at all (cf. entries VI 4, VII 4, VIII4, VII8, and VIII8 in Table 1), which corroborates the results obtained for the single-strand $\alpha$-helix turn IX2,3.31 However, several of the hairpin $\Delta \mathrm{E}_{\mathrm{GT}}$ 's are considerably larger than the helix $\Delta \mathrm{E}_{\mathrm{GT}}$ 's. The difference is quite conspicuous in the case of substitutions in several linkages that are exclusively $\mathrm{N}-\mathrm{H}$-acceptors, e.g., VI 1, VII 1, VIIII, and VIIII0. Such magnitudes of the destabilization effects suggest an additional loss of bonding upon mutations in the $\beta$-sheetlike fragments, vide infra. On the other hand, the data also indicate a number of possible compensating backbone-backbone interactions in the depsipeptide hairpins which in several instances seem to be quite flexible. Thus, the substitution next to the midturn peptide linkage can induce a rotation of the backbone chain which brings the NH group not involved in any $\mathrm{H}$-bond in the 'native' structure into the vicinity of the ester $\mathrm{O}$ group and the carbonyl $\mathrm{O}$ of the preceding peptide bond, see VII5 in Chart 3A. This may have some compensating effect (cf. entries VI5, VII5, VIII5, VII9, and VIII 9 in Table 1). Yet another compensating interaction may result from the donor-acceptor contacts $\mathrm{C}_{\mathrm{i}}=$ $\mathrm{O} \cdots \mathrm{C}_{\mathrm{j}}=\mathrm{O}$ as shown in Chart 3B $(\mathrm{i}=$ amide, $\mathrm{j}=$ ester; entries VII7 and VIII7 in Table 1): a rotation of the backbone chain enables the $0 \cdots \mathrm{C}_{\mathrm{j}}=\mathrm{O}$ approach in $\mathrm{VII} 7$ at the distance of $2.950 \AA$, and the $0 \cdots \mathrm{C}_{\mathrm{j}}=\mathrm{O}$ angle of $100^{\circ}$, which is optimal for a bonding interaction. ${ }^{32,33}$ The two effects seem to combine in the mutant VIII 7.

d. Ala $\rightarrow$ Lac Substitutions in Planar Parallel and Antiparallel $\beta$-Sheet Models. To avoid the complexity of the fully optimized $\beta$-hairpin models, we have examined several models assembled from the single strands which were kept in fixed conformations characteristic for the parallel and antiparallel $\beta$-sheets; see section 2 . The results are summarized in Table 3. The layout of the table 
TABLE 3. Group-Transfer Energies $\Delta E_{G T}\left(k\right.$ cal mol $\left.{ }^{-1}\right)$ for $m\left(m^{\prime}, m^{\prime \prime}\right)$ Ala $\rightarrow$ Lac Mutations of $\mathbf{N}$-Acetyl Polyalanine

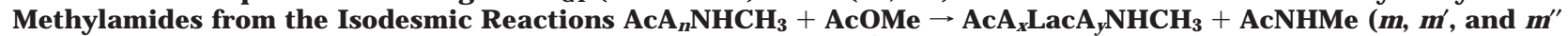
Denote the Mutation Sites) at the HF/3-21Ga and B3LYP/6-31G*b Levels

\begin{tabular}{|c|c|c|c|c|c|c|c|}
\hline \multirow[b]{2}{*}{ planar parallel } & \multirow[b]{2}{*}{$\mathrm{m}$} & \multirow{2}{*}{$\frac{\text { single strand }}{\mathbf{X I}}$} & \multicolumn{2}{|c|}{ double-stranded $\beta$-sheet } & \multicolumn{3}{|c|}{ triple-stranded $\beta$-sheet } \\
\hline & & & \multicolumn{2}{|c|}{$\mathbf{X I I}$} & \multicolumn{3}{|c|}{ XIII } \\
\hline tripeptide & 1 & 3.3 & 11.0 & 4.9 & 14.4 & 13.7 & 5.3 \\
\hline $\mathrm{AcA}_{2} \mathrm{NHME}$ & 2 & 6.0 & 8.1 & 17.5 & 7.9 & 20.1 & 18.6 \\
\hline & 3 & 3.2 & 10.1 & 4.3 & 12.6 & 13.1 & 4.7 \\
\hline planar parallel & $\mathrm{m}$ & XIV & \multicolumn{2}{|c|}{$\mathbf{X V}$} & & & \\
\hline tetrapeptide & 1 & 3.4 & 12.3 & 5.3 & & & \\
\hline $\mathrm{AcA}_{3} \mathrm{NHME}$ & 2 & 5.9 & 7.3 & 16.7 & & & \\
\hline & 3 & 5.8 & 16.6 & 8.1 & & & \\
\hline & 4 & 3.3 & 4.7 & 11.2 & & & \\
\hline planar antiparallel & $m$ & $\mathbf{X V I}$ & \multicolumn{2}{|c|}{ XVII } & \multicolumn{3}{|c|}{ XVIII } \\
\hline tripeptide & 1 & 4.9 & 12.5 & 7.4 & 14.5 & 15.1 & 7.5 \\
\hline \multirow[t]{2}{*}{$\mathrm{ACA}_{2} \mathrm{NHMe}$} & 2 & 7.5 & 9.5 & 18.9 & 9.1 & 21.1 & 19.2 \\
\hline & 3 & 2.2 & 12.7 & 3.3 & 13.9 & 14.8 & 3.6 \\
\hline planar antiparallel & $\mathrm{m}$ & $\mathbf{X I X}$ & $x x$ & $\mathbf{X X I}$ & & & \\
\hline tetrapeptide & 1 & 5.5 & 7.6 & 12.9 & & & \\
\hline \multirow[t]{3}{*}{$\mathrm{AcA}_{3} \mathrm{NHMe}$} & 2 & 7.1 & 17.5 & 8.9 & & & \\
\hline & 3 & 7.5 & 10.7 & 18.0 & & & \\
\hline & 4 & 2.3 & 13.0 & 3.5 & & & \\
\hline
\end{tabular}

a The total energies of the "wild-type" structures at the HF/3-21G level: XI, $-734.5942875 ; \mathbf{X I I},-1469.2446175 ; \mathbf{X I I I},-2203.8988627$; XIV, -979.0759374; XV, -1958.2272421; XVI, -734.5975173; XVII, -1469.2510859; XVIII, -2203.9087552; XIX, -979.0809868; XX -1958.2430951; XXI, - 1958.2311767 (hartrees). ${ }^{\mathrm{b}}$ The group transfer energies $\Delta \mathrm{E}_{\mathrm{GT}}\left(\mathrm{kcal} \mathrm{mol}^{-1}\right)$ at the B3L YP/6-31G* level for the selected structures: XI1-3, 0.9, 3.3, 1.7; XVI 1-3, 1.4, 4.5, 2.2; XVIII 2,3, 5.8, 7.9; $\mathbf{1}^{\prime}, 2$, 9.1, 13.9; 1'”-3', 4.9, 12.2, 2.2; XIX1-4, 1.5, 4.5, 4.3, 2.5.

\section{CHART 4. Planar Parallel and Antiparallel $\beta$-Sheet Models XIII (A) and XVIII (B) and the Selected Backbone Interactions ${ }^{\mathrm{a}}$}

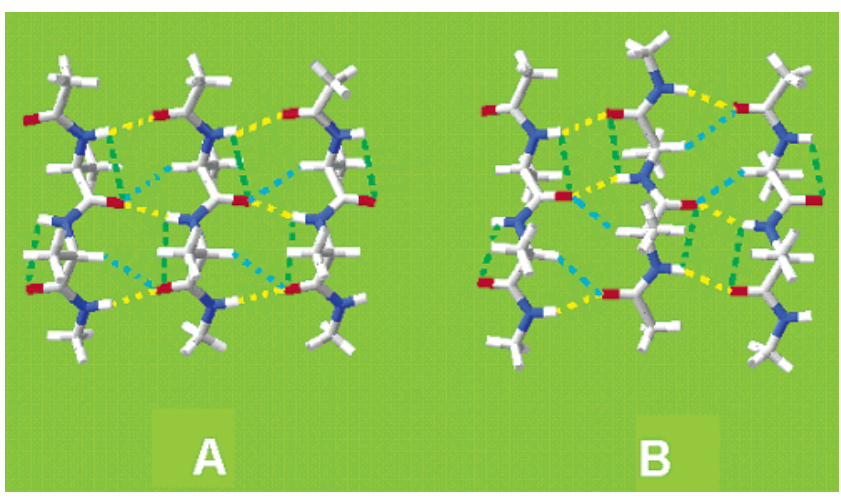

a The numbering of residues (and the mutation sites) begins in XIII at the $\mathrm{H}$-bond donor $\mathrm{N}$-terminus in the upper left corner of the diagram and continues at the top ( $\mathrm{N}$-terminus) of the neighboring (central) strand. The interstrand backbone-backbone $\mathrm{C}=\mathrm{O} \cdots \mathrm{HN}$ bonds are color-coded yellow, the most important $\mathrm{C}=\mathrm{O} \cdots \mathrm{HC}_{\alpha}$ interactions are color-coded blue, and the most important intrastrand backbone-backbone $\mathrm{C}=\mathrm{O} \cdots \mathrm{HN}$ bonds are shown in green.

is meant to reflect the topology of the model structures as shown in Charts 4 and 5.

For instance, the data for mutations of the triplestranded parallel $\beta$-sheet model XIII, shown in Chart 4A, are listed beginning with the $\mathrm{H}$-bond donor $\mathrm{N}$-terminus (the upper-left corner of the chart) in the left-most column, the index $\mathrm{m}$ denoting the mutation site; the second column list the data for the central strand, beginning at the top again, with the index $\mathrm{m}^{\prime}$ etc. Consequently, the entries in a row represent values for a perpendicular array of $\mathrm{H}$-bonded peptide bonds, labeled $m, m^{\prime}, m^{\prime \prime}$. Only one column of the data is given for the
CHART 5. Planar Antiparallel $\beta$-Sheet Models XX ( $A$, the LSL Sequence of the H-Bonded Rings) and XXI (B, the SLS Sequence), and Selected Backbone Interactions ${ }^{\mathrm{a}}$

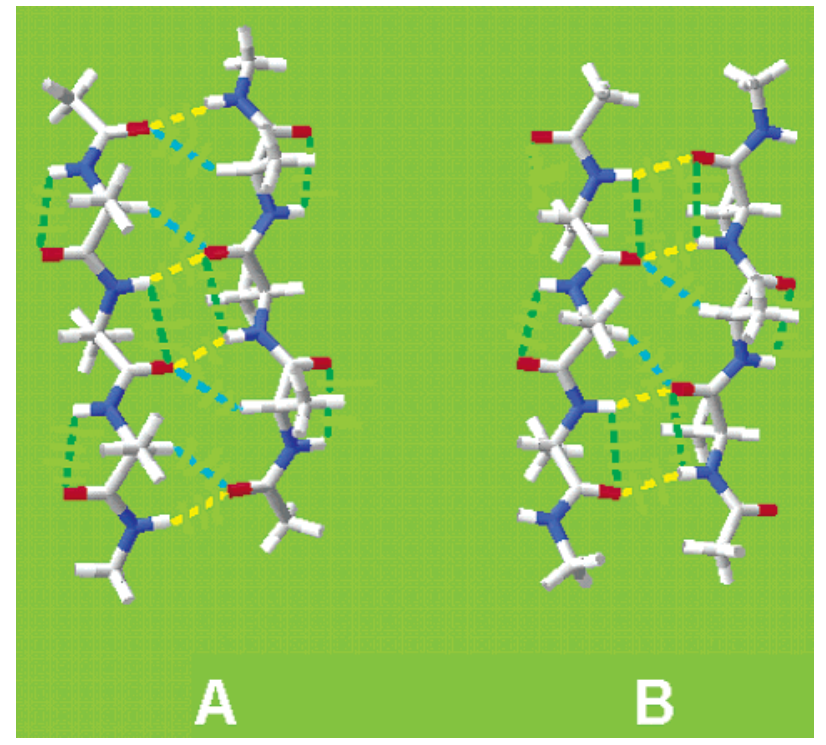

a In both cases, the numbering begins at the $\mathrm{N}$-terminus in the upper left corner; the two strands are related by the 2-fold axis. The interstrand backbone-backbone $\mathrm{C}=\mathrm{O} \cdots \mathrm{HN}$ bonds are colorcoded yellow, the most important interstrand $\mathrm{C}=\mathrm{O} \cdots \mathrm{HC}_{\alpha}$ interactions are color-coded blue, and the most important intrastrand backbone-backbone $\mathrm{C}=\mathrm{O} \cdots \mathrm{HN}$ bonds are shown in green.

structures $\mathbf{X X}$ and $\mathbf{X X \mathbf { I }}$ shown in Chart $5 \mathrm{~A}$ and Chart $5 B$, respectively, since the two strands in these alternative antiparallel tetrapeptide complexes are related by the 2-fold axis (note the sequence LSL in Chart 5A (XXX) and SLS in Chart 5B (XXI), S and $L$ referring to the small and large $\mathrm{H}$-bonded rings). 


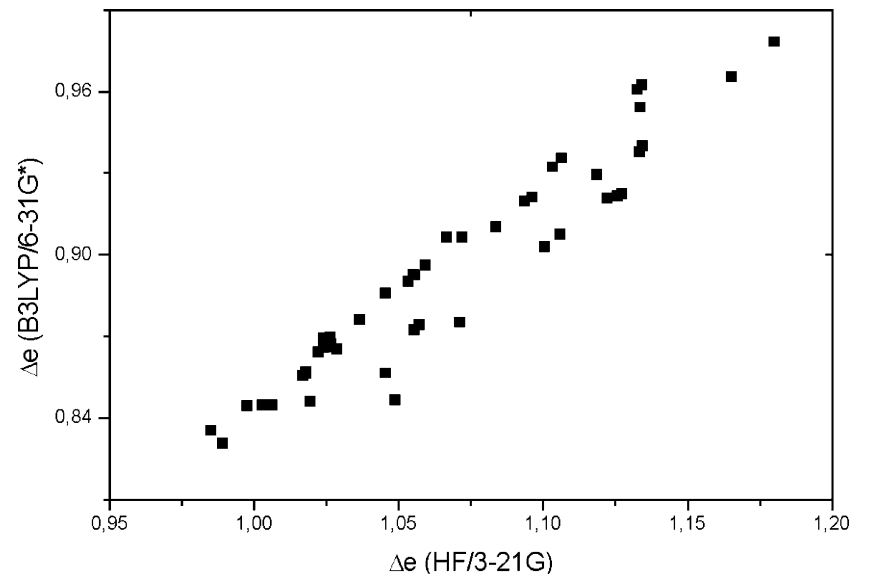

FIGURE 3. Charge polarization of the peptide bonds $\Delta \mathrm{e}(\mathrm{au})$ in the antiperiplanar $\beta$-sheet model $\mathbf{X V I I I}$, its two depsipeptide mutants $\mathbf{X V I I I} 2$ and $\mathbf{X V I I I I}$, and in strands $\mathbf{X I X}$ (Table 3) and $\mathbf{I X}^{31}$ (constrained optimizations) at the HF/3-21G and B3LYP/6-31G* levels of the theory.

The range of the $\Delta \mathrm{E}_{\mathrm{GT}}$ values is significantly greater for the present $\beta$-sheet models than for the $3_{10^{-}}$and $\alpha$-helix models. There could be two major reasons for that increase. In contrast to the results obtained for the non$\mathrm{H}$-bonded peptide linkages in the $\alpha$-helix turn or $\beta$-hairpin, Ala $\rightarrow$ Lac mutations in the single extended strands $\mathbf{X I}, \mathbf{X I V} \mathbf{V} \mathbf{X V I}$, and $\mathbf{X I X}$, are considerably endothermic (Table 3), hence the large destabilization effects in the $\beta$-sheet fragments are due in part to loss and weakening of the intrastrand $\mathrm{C}=\mathrm{O} \cdots \mathrm{H}-\mathrm{N}$ bonding. ${ }^{36}$ The second destabilizing contribution could be due to loss of the interstrand $\mathrm{C}=\mathrm{O} \cdots \mathrm{H}-\mathrm{C}^{\alpha}$ bonding. Numerous structural data indicate that there is an additional interstrand bonding in the $\beta$-sheets between the peptide carbonyl $\mathrm{O}$ and the $\mathrm{C}^{\alpha}-\mathrm{H} ; 37,38$ the strength of such interactions was estimated to approach $1.1-2.6 \mathrm{kcal} \mathrm{mol}^{-1}$ in formamide and $\mathrm{N}$-methylacetami de dimers. ${ }^{39,40}$ The most important interactions of the two types are indicated in Charts 4 and 5 in addition to the regular $\mathrm{C}=\mathrm{O} \cdots \mathrm{H}-\mathrm{N}$ bonds between the adjacent peptide chains. The corresponding distances, e.g. in the fully optimized structure VIII, are 2.370-2.448 $\AA$ for the $\mathrm{C}=\mathrm{O} \cdots \mathrm{H}-\mathrm{C}^{\alpha}$ interactions, and 2.186-2.382 $\AA$ for the "intrastrand" $\mathrm{C}=\mathrm{O} \cdots \mathrm{H}-\mathrm{N}$ interactions (HF/3-21G).

The charge-polarization parameters $\Delta$ efor the peptide bonds in several $3_{10}$-hel ix structures obtained at the HF/ 3-21G and B3LYP/6-31G* levels were compared in Figure 2 . The analogous plot for the present $\beta$-sheet models shows a somewhat greater scatter, Figure 3 , but the correlation supports the earlier conclusion that the HF/ 3-21G model is qual itatively useful in reproducing charge distribution in the peptide chains.

(36) Shamovsky, I. L.; Ross, G. M.; Riopelle, R. J . Phys. Chem. B 2000, 104, 11296.

(37) Derewenda, Z. S.; Derewenda, U.; Kobos, P. M. J . Mol. Biol. 1994, 241, 83. Derewenda, Z. S.; Lee, L.; Derewenda, U. J . Mol. Biol. 1995, 252, 248. Bella, J .; Berman, H. M. J . Mol. Biol. 1996, 264, 734.

(38) Lee, K. M.; Chang, H.-C.; J iang, J -C.: Chen, J . C. C.; Kao, H.E.; Lin, S. H.; Lin, I. J. B. J . Am. Chem. Soc. 2003, 125, 12358.

(39) Vargas, R.; Garza, J .; Dixon, D. A.; Hay, B. P. J . Am. Chem. Soc. 2000, 122, 4750 .

(40) Vargas, R.; Garza, J .; Friesner, R. A.; Stern, H.; Hay, B. P.; Dixon, D. A. J . Phys. Chem. A 2001, 105, 4963.

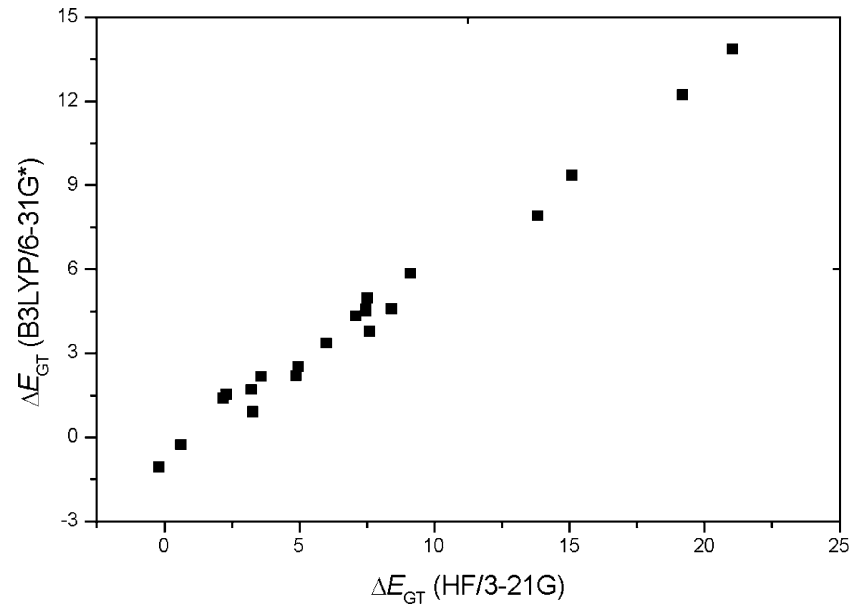

FIGURE 4. Group-transfer energies $\Delta \mathrm{E}_{\mathrm{GT}}\left(\mathrm{kcal} \mathrm{mol}^{-1}\right)$ for the $3_{10}$-helices 14, II6, the antiperiplanar $\beta$-sheet model mutants

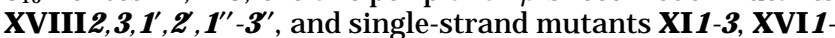
3, XIX1-4 (cf. Table 3, and footnote b), and IX2,331 at the HF/ 3-21G and B 3LYP/6-31G* levels of the theory.

\section{Comparison of the Group-Transfer Energies at the HF/3-21G and B3L YP/6-31G* Levels}

Since the HF level of theory using the 3-21G basis set significantly overestimates the energy of hydrogen bonds, ${ }^{41}$ the question arises how reliable are the values listed in Tables 1 and 3. To address this question, reoptimizations at the B $3 L$ YP/6-31G* level were carried out for a number of structures which define the obtained range of the group-transfer energies-the two $3_{10}$-helices (I, II), the triple-stranded antiperiplanar $\beta$-sheet (XVIII), and single strands in the extended (XI, XVI, XIX) and helical (IX) conformations, ${ }^{31}$ al ong with the corresponding depsipeptide mutants. All these data are combined in the plot in Figure 4. The correlation with the slope of 0.67 is quite satisfactory. The slope reflects the changes in the $\Delta \mathrm{E}_{\mathrm{GT}}$ values in the extended strands (Table 3 , footnote $b$ ), whereas the actual scaling back of the HF/3-21G $\Delta \mathrm{E}_{\mathrm{GT}}$ 's in several cases of the $3_{10}$-helix mutations is closer to 0.5 .

\section{Origin of the Destabilization Effects; Partitioning of the Group-Transfer Energy into Lost H-Bonds, Decrease in Lewis Basicity of the C $=$ O Group, and O… Repulsion}

It seems reasonable to assume that the variation in charge polarization of the peptide bonds and in the CO... $\mathrm{HN}$ separation reflect the variation in the strength of backbone $\mathrm{H}$-bonding. ${ }^{42,43}$ It is therefore significant that the destabilizing effects of Ala $\rightarrow$ Lac mutations, i.e., the group-transfer energies, correlate with the degree of charge polarization of the mutated peptide linkages measured by the difference $\Delta \mathrm{e}$ in Mulliken populations at $\mathrm{H}$ and $\mathrm{O}$ in $\mathrm{HN}-\mathrm{C}=\mathrm{O}$, and with with the $\mathrm{H}$-bond

(41) Frisch, M. J .; Del Bene, J . E.; Binkley, J . S.; Schaefer, H. F. III. J. Chem. Phys. 1986, 84, 2279. Cramer, C. J. Essentials of Computational Chemistry; J ohn Wiley \& Sons: Chichester, 2002; pp 179-181.

(42) J effrey, G. A. An Introduction to Hydrogen Bonding; Oxford University Press: Oxford, 1997. Steiner, T. Angew. Chem., Int. Ed. 2002, 41, 48.

(43) Harris, T. K.; Mildvan, A. S. Proteins: Struct., Funct., Genet. 1999, 35, 275. Kang, Y. K. J . Chem. Phys. B 2000, 104, 8321. 


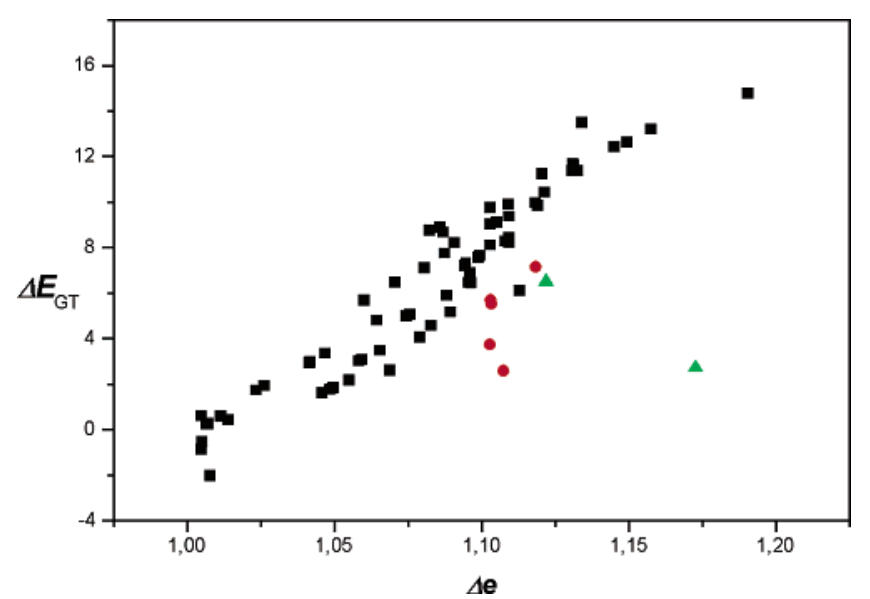

FIGURE 5. Dependence of the group-transfer energy $\Delta \mathrm{E}_{\mathrm{GT}}$ (kcal mol ${ }^{-1}$ ) for $\mathrm{mA} \rightarrow$ Lac mutations of $\mathrm{N}$-acetyl polyalanyl amides on the difference $\Delta \mathrm{e}(\mathrm{au})$ in $\mathrm{H}$ and $\mathrm{O}$ Mulliken populations of the substituted $\mathrm{m}$ peptide bond $\mathrm{HNC}=\mathrm{O}$ : the data from the unconstrained optimizations of the helical and hairpin conformers (Table 1). The color-coded data sets represent mutants with compensatory backbone interactions resulting from the $\mathrm{i}, \mathrm{i}+3 \leftrightarrow \mathrm{i}, \mathrm{i}+4$ transitions (red) or donoracceptor contacts/H-bonding (green).

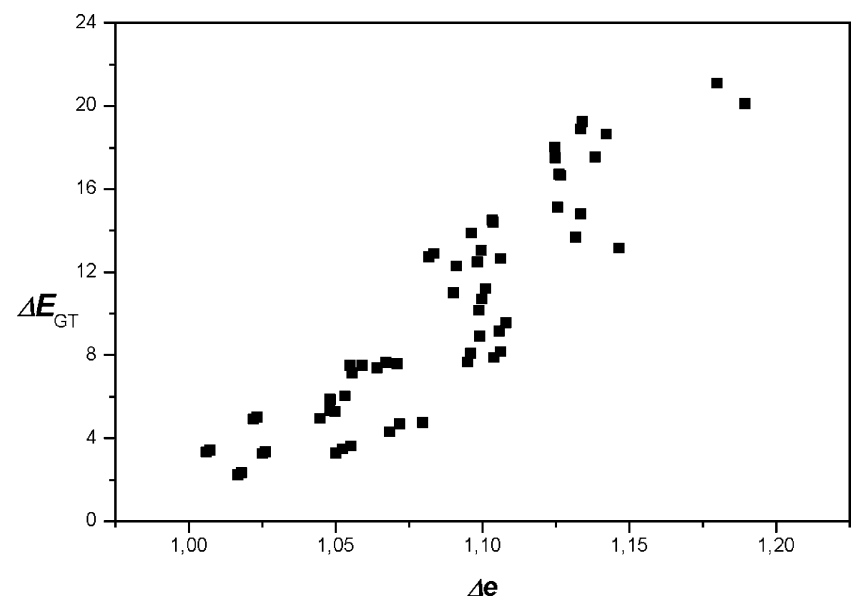

FIGURE 6. Dependence of the group-transfer energy $\Delta \mathrm{E}_{\mathrm{GT}}$ $\left(\mathrm{kcal} \mathrm{mol}^{-1}\right)$ for $\mathrm{mA} \rightarrow \mathrm{Lac}$ mutations of $\mathrm{N}$-acetyl polyalanyl methylamides on the difference $\Delta \mathrm{e}(\mathrm{au})$ in $\mathrm{H}$ and $\mathrm{O}$ Mulliken populations of the substituted $\mathrm{m}$ peptide bond $\mathrm{HN}-\mathrm{C}=\mathrm{O}$ : the data from constrained optimizations (see Computational Methods) of the planar parallel and antiparallel $\beta$-sheet models (Table 3).

distances in the "wild-type" structures. The $\Delta \mathrm{E}_{\mathrm{GT}}$ vs $\Delta \mathrm{e}$ plot in Figure 5 shows a reasonable correlation for the helix and hairpin mutants with the preserved "native" structure and pattern of backbone-backbone interactions. For the remaining mutants (the data marked with asterisks in Table 1, and color-coded in Figure 5), the $\Delta \mathrm{E}_{\mathrm{GT}}$ values deviate from the overall distribution in a manner consistent with attenuation of the loss of bonding as described earlier.

A similar plot is obtained for the constrained $\beta$-sheet models, Figure 6.

Finally, the dependence of the group-transfer energies on the $\mathrm{H}$-bond distances can be tested on the samples including the peptide bonds involved exclusively either as $\mathrm{N}-\mathrm{H}$-donors or $\mathrm{N}-\mathrm{H}$-acceptors. The plots for the

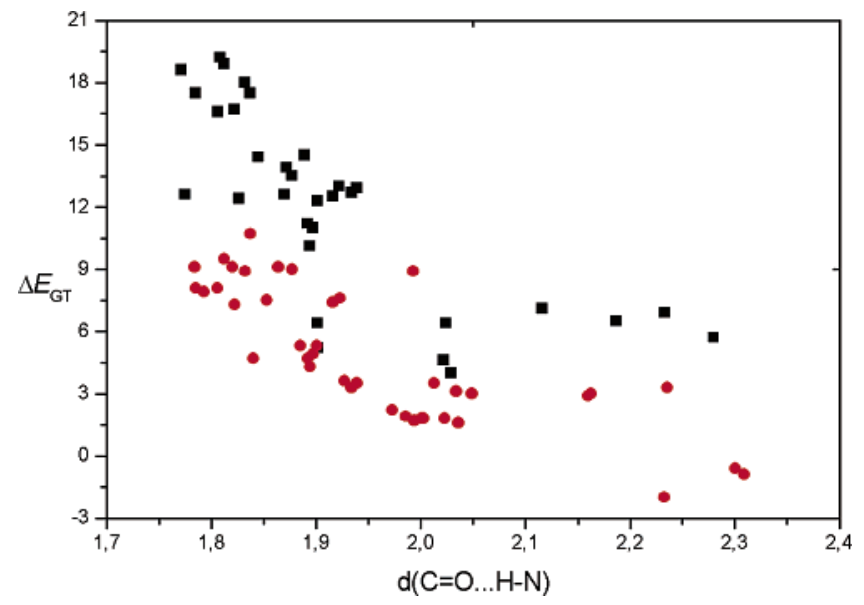

FIGURE 7. Dependence of the group-transfer energy $\Delta \mathrm{E}_{\mathrm{GT}}$ ( $\mathrm{kcal} \mathrm{mol}^{-1}$ ) on the $\mathrm{H}$-bond distance in the "wild-type" structure $(\AA)$ : (A) black squares represent substitutions in the peptide linkages that are exclusively $\mathrm{NH}$-bond donors; (B) red circles represent substitutions in the peptide linkages that are exclusively $\mathrm{NH}$-bond acceptors. The $\Delta \mathrm{E}_{\mathrm{GT}}$ data aretaken from both Tables 1 and 3.

combined data from Tables 1 and 3 are shown in Figure 7: in each $\Delta E_{\mathrm{GT}}$ sample, the correlation does seem to account for a major fraction of variance.

The correlations shown in Figures $5-7$ suggest that loss or weakening of a hydrogen bond do usually constitute a major contribution to the destabilization effect of the Ala $\rightarrow$ Lac mutation, and the partitioning of the group-transfer energies should yield reasonable estimates of the electronic association energy of the backbonebackbone $\mathrm{H}$-bonds. To discuss such a partitioning, it is convenient to distinguish four categories of the peptide linkages that are mutated in this study: (i) $\mathrm{N}-\mathrm{H}-$ acceptor bonds; (ii) $\mathrm{N}-\mathrm{H}$-donor bonds; (iii) bonds that are simultaneously $\mathrm{N}-\mathrm{H}$-acceptors and $\mathrm{N}-\mathrm{H}$-donors; (iv) bonds that do not participate in $\mathrm{H}$-bonding.

In the first case, the mutations do not remove any $\mathrm{C}=$ $\mathrm{O} \cdots \mathrm{H}-\mathrm{N}$ bonds, but merely weaken the extant ones. The destabilization is expected because of the difference in the dipole moments and Lewis basicity of the esters and the amides, ${ }^{44}$ but the effect cannot be very large. Abraham's H-bond structural group constants ${ }^{45}$ predict $\sim 1-2$ log unit difference in 1:1 complexation constants in the gas phase. ${ }^{46}$ This estimate is quite consistent with the magnitude of the quoted above $\Delta \mathrm{E}_{\mathrm{GT}}$ 's for I1-IV1, considering that the HF/3-21G values of the grouptransfer energies scale back at the higher level of theory, vide supra, by the factor of $0.5-0.7$. As was already mentioned, the much larger destabilization effects resulting from substitutions in the $\beta$-sheet $\mathrm{N}-\mathrm{H}$-acceptor peptide linkages suggest an additional loss of bonding. One of such additional contributions could be the intrastrand $\mathrm{H}$-bonding which is quite large in the extended single strands, see Table 3: the corresponding distances

(44) Ethyl acetate DN $=17.1, \mathrm{~N}$-methyl acetamide $\mathrm{DN}=26.6$ : Gutmann, V. TheDonor-Acceptor Approach to Mol ecular Interactions: Plenum Press: New York, 1978. Ethyl acetate $u=1.90 \mathrm{D}, \mathrm{N}$-methyl acetamide $\mu=4.42 \mathrm{D}$ : Vogel, P. Chimie Organique; De Boeck Université: Bruxelles, 1997.

(45) Abraham, M. H.; Platts, J . A. J . Org. Chem. 2001, 66, 3484.

(46) Marco, J .; Orza, J . M.; Notario, R.; Abboud, J .-L. M. J . Am. Chem. Soc. 1994, 116, 8841. 
in the fully optimized structure VIII are $2.186-2.382 \AA$ for the "intrastrand" $\mathrm{C}=\mathrm{O} \cdots \mathrm{H}-\mathrm{N}$ interactions. In the case of the constrained $\beta$-sheet models, this contribution can be separated since by definition (Hess's Law), the loss of electronic association energy $\Delta D_{e}$ due to an Ala $\rightarrow$ Lac mutation is equal to the difference of the group-transfer energies for the binary or ternary complex and the corresponding single extended strand $\Delta D_{e}=$ $\Delta \mathrm{E}_{\mathrm{GT}}(\mathrm{SSm})-\Delta \mathrm{E}_{\mathrm{GT}}(\mathrm{Sm})$. Some of the energies obtained this way are slightly larger than the $\Delta \mathrm{E}_{\mathrm{GT}}$ 's for the helix mutants I 2-V2, which is perhaps an indication of a small contribution of the interstrand $\mathrm{C}=\mathrm{O} \cdots \mathrm{H}-\mathrm{C}^{\alpha}$ interactions, see section $3 \mathrm{~d}$. Thus, the overall range of the destabilization effects due to the decrease in $\mathrm{C}=\mathrm{O}$ basicity is $1.1-$ $2.6 \mathrm{kcal} \mathrm{mol}^{-1}$ (HF/3-21G; B3LYP/6-31G* estimate $0.7-$ $1.7 \mathrm{kcal} \mathrm{mol}^{-1}$ ).

In the second case, the Ala $\rightarrow$ Lac mutations in the helical $\mathrm{N}-\mathrm{H}$-donor bonds remove one $\mathrm{H}$-bond and introduce a close $\mathrm{O} \cdots \mathrm{O}$ contact, while the mutations in the $\beta$-sheet $\mathrm{N}-\mathrm{H}$-donor bonds in addition remove an intrastrand $\mathrm{H}$-bonds. Thus, the $\Delta \mathrm{E}_{\mathrm{GT}}$ 's for mutants $16,7, \mathbf{1 1 8 , 9}$, III8,9,10, IV12,13,14, and V9,10 (Table 1) and the

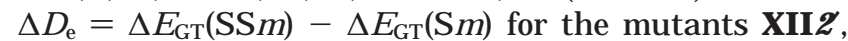
XIII2', XV3,2', XVII2', XVIII' ', XX2, and XXI3 (Table 3) primarily comprise the loss of $\mathrm{H}$-bond and the $\mathrm{O} \cdots \mathrm{O}$ repulsion. By analogy to the experimental approach, ${ }^{19}$ an estimate of the latter contribution can be based on a comparison of the group-transfer energies for Ala $\rightarrow$ Lac mutations $(\mathrm{N}-\mathrm{H} \rightarrow \mathrm{O}$ replacement) with the grouptransfer energies for Ala $\rightarrow$ I ba (isobutyric acid) mutations which substitute the peptide linkage with the keto methylene moiety: $\mathrm{ACA}_{n} \mathrm{NHR}+\mathrm{MeCOCH}_{2} \mathrm{Me} \rightarrow \mathrm{AcA}_{x^{-}}$ $\mathrm{CH}_{2} \mathrm{CH}\left(\mathrm{CH}_{3}\right) \mathrm{COA}_{\mathrm{y}} \mathrm{NHR}+\operatorname{MeCONHMe}\left(\mathrm{R}=\mathrm{H}, \mathrm{CH}_{3}\right)$ $\left(\mathrm{N}-\mathrm{H} \rightarrow \mathrm{CH}_{2}\right.$ replacement, the group-transfer reaction between a peptide and ethylmethyl ketone). The corresponding optimizations (HF/3-21G) were made for the Ala $\rightarrow$ I ba mutations I5C (11.1), I7C (7.8), III 7C (11.6), III9C (10.1), IX2C (6.6), IX3C (7.2), XVI2C (5.6), XIX2C (5.4), XIX3C (5.6), and XVII2'C (13.2) (all bracketed values in $\mathrm{kcal}^{\mathrm{mol}}{ }^{-1}$ ). The substitutions in the single helix turn $\mathbf{X}$ are in this case highly endothermic, av. $6.9 \mathrm{kcal}$ $\mathrm{mol}^{-1}$, compared to $0.2 \mathrm{kcal} \mathrm{mol}^{-1}$ for the Ala $\rightarrow \mathrm{Lac}$ mutations; ${ }^{31}$ the substitutions in the single extended strands $\mathbf{X V} \mathbf{I}$ and $\mathbf{X I} \mathbf{X}$ are slightly less endothermic than the Ala $\rightarrow$ Lac mutations, av. $5.5 \mathrm{kcal} \mathrm{mol}^{-1}$. If these values are used to "correct" the group-transfer energies quoted above in the brackets, and the resulting figures are subtracted from the Ala $\rightarrow \mathrm{Lac} \Delta \mathrm{E}_{\mathrm{GT}}$ 's, the differences average to $3.0 \mathrm{kcal} \mathrm{mol}^{-1}$ in the case of the $3_{10}$-helices, where the $0 \cdots 0$ separation is $3.5-3.7 \AA$, see section $3 a$, and to $3.6 \mathrm{kcal} \mathrm{mol}^{-1}$ in the case of the $\alpha$-helices and $\beta$-sheets, where the $0 \cdots 0$ separation is $3.0-3.2 \AA$. Thus, the B3LYP/6-31G* estimate of the $0 \cdots 0$ repulsion effect, see section 4, is $1.5-2.4 \mathrm{kcal} \mathrm{mol}^{-1}$. Boger et al. estimate of the $\Delta \Delta \mathrm{G}^{\circ}$ due to $0 \cdots 0$ repulsion is $2.6 \mathrm{kcal} \mathrm{mol}^{-1}$ from a comparison of the vancomycin and vancomycin aglycon binding affinity for $A c(A c K)^{D} A^{D} A$ and $A c(A c K)^{D} A^{D} L$ ac vs $\mathrm{Ac}(\mathrm{AcK})^{\mathrm{D} A l} \mathrm{ba}$, the latter ligand incorporating $\mathrm{CH}_{2}$ in place of the amide $\mathrm{NH}^{19}$

In the case of the third category, the Ala $\rightarrow$ Lac mutations at the peptide bonds that are simultaneously $\mathrm{N}-\mathrm{H}$-acceptors and $\mathrm{N}-\mathrm{H}$-donors, the destabilization effect comprises three major contributions in a helix, and four major contributions in a $\beta$-sheet. With the above estimates of these contributions in hand, and assuming that the effect of $\mathrm{C}=\mathrm{O}$ basicity is slightly larger for the peptide bonds in the helix interior than in its first turn (i.e. $2.0 \mathrm{kcal} \mathrm{mol}{ }^{-1}$ in the $3_{10}$-helix, $2.5 \mathrm{kcal} \mathrm{mol}^{-1}$ in the $\alpha$-helix, HF/3-21G), one can now estimate the electronic binding energies of the backbone-backbone $\mathrm{C}=\mathrm{O} \cdots \mathrm{HN}$ interactions. Using the data for the mutations I I6, IV9, and XIII 2", and scaling the results to the B3LYP/6-31G* level, the following maximum values are obtained for the presently examined set of the secondary structure models: $3_{10}$-helix $D_{e}=-1.7 \mathrm{kcal} \mathrm{mol}^{-1}, \alpha$-helix $\mathrm{D}_{\mathrm{e}}=-3.8$ kcal $\mathrm{mol}^{-1}$, and $\beta$-sheet $\mathrm{D}_{\mathrm{e}}=-6.1 \mathrm{kcal} \mathrm{mol}^{-1}$.

The observed trend in estimated $D_{\mathrm{e}}$ 's is consistent with the earlier results of quantum-mechanical calculations on the isolated amide model systems ${ }^{47}$ and with the available spectroscopic and structural evidence.22 In contrast, molecular mechanics calculations yield reverse ordering of the $\alpha$-helix and $\beta$-sheet $\mathrm{H}$-bonding energies. ${ }^{48}$ This might be a consequence of using the same partial charges for both folds; it has also been suggested that the force fields using atom-centered partial charges cannot give rel iable dependence of $\mathrm{H}$-bonding energetics on geometry. ${ }^{49}$

It should be noted that $D_{\mathrm{e}}$ 's based on the group-transfer energies do not seem to capture the entire stabilization effect of $\mathrm{H}$-bond formation in the complexes of polypeptides. For instance, the B3LYP/6-31G* data for XVI 2 and XVIII 2" give $\beta$-sheet $\mathrm{D}_{\mathrm{e}}=-7.7 \mathrm{kcal} \mathrm{mol}^{-1}$ without any correction for $0 \cdots O$ repulsion, and $D_{e}=-5.3 \mathrm{kcal} \mathrm{mol}^{-1}$ with such a correction. On the other hand, the average values $D_{e}=-7.8$ or $-8.6 \mathrm{kcal} \mathrm{mol}^{-1}$ are obtained using the total energies of $\mathbf{X V I I I}$ and $\mathbf{X V I}$ or the total energies of XVIII and its isolated strands (from single point calculations), respectively. Assuming that the repulsion effect is properly accounted for, the difference can perhaps be attributed to the interstrand $\mathrm{C}=\mathrm{O} \cdots \mathrm{H}-\mathrm{C}^{\alpha}$ interactions, see Section 3d, and to the stabilization of the individual strands upon formation of the three stranded $\beta$-sheet. The latter possibility highlights the difficulty in isolating the "hydrogen bonding" energy in the case of interaction of two polar groups embedded in a polypeptide chain and will be discussed elsewhere.

\section{Conclusions}

Site-directed mutagenesis provides a wealth of experimental information which is often inherently difficult to interpret. This is particularly true in regard to the problem of secondary structure stability, since the local interactions might include nonclassical contributions (secondary bonding) which cannot be examined without quantum-mechanical calculations. One possible way to approach this problem is to describe a mutation in terms of an isodesmic equation. It seems now, at least in the case of the Ala $\rightarrow$ Lac substitutions, that this approach can indeed be successful. Heats of the group-transfer reactions between peptides and methyl acetate, $\Delta \mathrm{E}_{\mathrm{GT}}$ (Scheme 1), are found to be quite sensitive to the features

(47) Mitchell, J . B. O.; Price, S. L. J . Comput. Chem. 1990, 11, 1217. (48) Lazaridis, T.; Archontis, G.; Karplus, M. Adv. Protein Chem. 1995, 47, 231. Sheu, S.-Y.; Yang, D.-Y.; Selzle, H. L.; Schlag, E. W. Proc. Natl. Acad. Sci. U.S.A. 2003, 100, 12683.

(49) Beachy, M. D.; Chasman, D.; Murphy, R. B.; Halgren, T. A.; Friesner, R. A. J . Am. Chem. Soc. 1997, 119, 5908. 
of secondary structure. Destabilizing effects of such mutations are absent in type I turns, small in the $3_{10^{-}}$ helices, somewhat greater in the $\alpha$-helices, and quite large in the $\beta$-sheet models; $\Delta \mathrm{E}_{\mathrm{GT}}$ 's also tend to increase upon extension of the $\mathrm{H}$-bonded array of peptide linkages. ${ }^{50}$ Qualitatively, this picture is independent of the level of the theory employed since the HF/3-21G and B3L YP/6-31G* $\Delta \mathrm{E}_{\mathrm{GT}}$ 's show a good correlation with the slope of 0.67, cf. Figure 7. In several depsipeptide mutants, the "wild-type" H-bonding pattern and molecular geometry are distorted by compensating backbonebackbone interactions. In all other cases, the grouptransfer energies correlate with the $\mathrm{H}$-bond distances in the "wild-type" structures, and with the charge-polarization indices of the mutated peptide linkages. Partitioning of the group-transfer energies into loss of interstrand and intrastrand $\mathrm{H}$-bonds, decrease in $\mathrm{C}=\mathrm{O}$ basicity, and O $\cdots$ repulsion, yields the following B $3 L Y P / 6-31 G *$ estimates of the maximum electronic association energies of the backbone-backbone $\mathrm{C}=\mathrm{O} \cdots \mathrm{HN}$ bonds in the presently examined model structures: $3_{10}$-helix $D_{e}=-1.7$ kcal mol ${ }^{-1}, \alpha$-helix $D_{e}=-3.8 \mathrm{kcal} \mathrm{mol}^{-1}$, and $\beta$-sheet $\mathrm{D}_{\mathrm{e}}$ $=-6.1 \mathrm{kcal} \mathrm{mol}^{-1}$. These assessments will be affected by inclusion of the medium and specific solvation effects, the vibrational contributions, and the improvement of the theoretical model. Nonetheless, such corrections seem unlikely to alter in any fundamental way the emerging

(50) This is consistent with the view which attributes cooperativity in the helix formation to the strengthening of the backbone-backbone $\mathrm{H}$-bonds (see, for instance: Miller, J . S.; Kennedy, R. J .; Kemp, D. S. J . Am. Chem. Soc. 2002, 124, 945; and ref 28b); this view has recently been questioned, ref 29a. For the evidence that $\beta$-sheet formation is cooperative in perpendicular direction see: Schenck, H. L.; Gellman, S. H. J . Am. Chem. Soc. 1998, 120, 4869. For the opposing view: Zhao, Y.-L.; Wu, Y.-D. J . Am. Chem. Soc. 2002, 124, 1570. picture of considerable variation in charge polarization of the peptide bonds, and in the stabilization that the backbone interactions provide, in different elements of secondary structure. Thus, our findings corroborate the recent proposition that electronic configuration of the peptide bonds can vary along the amide rehybridization/ polarization path, and that the optimal stability of a given element of secondary structure requires a specific location of its peptide bonds along this path; 51 since electronic configuration of a peptide bond depends inter alia on the inductive and hyperconjugative side chainpeptide bond interactions, secondary structure stability may also depend on electronic properties of the amino acid side chains.

Acknowledgment. We thank the administration of the High-Performance Computer Center at Bilkent University for the generous access to the center facilities. The parallelized version of Gaussian 98, Revision A. 7, ${ }^{30}$ was installed on the Sun Enterprise 4500 Server by Professor Ulrike Salzner of the Department of Chemistry, Bilkent University.

Supporting Information Available: Gaussian98 archive entries (the Cartesian coordinates and the total energies) for the peptide, depsipeptide, and auxiliary structures. This material is available free of charge via the Internet at http://pubs.acs.org.

\section{J 00358372}

(51) Cieplak, A. S. In The Amide Linkage: Selected Structural Aspects in Chemistry, Biochemistry and Materials Science; Greenberg, A., Breneman, C., Liebman, J. F., Eds.; J ohn Wiley \& Sons: New York, 2000; Chapter 17, pp 565-597. Cieplak, A. S. Chem. Rev. 1999, 99, 1265. Cieplak, A. S. Struct. Chem. 1994, 5, 85. Cieplak, A. S. J . Am. Chem. Soc. 1985, 107, 271. 